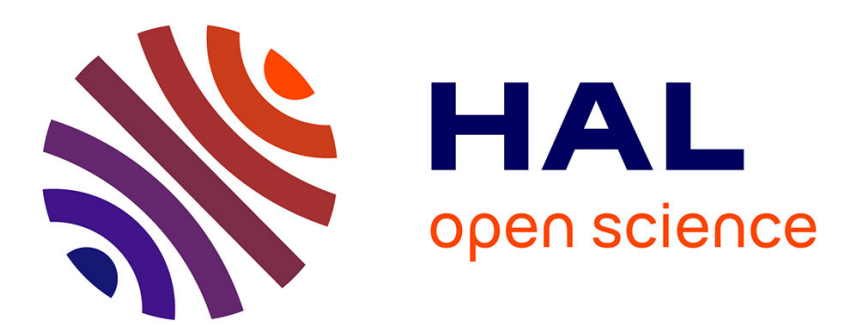

\title{
Income inequalities and international trade in goods and services: short and long-run evidence
}

\author{
Nicolas Fleury, Sylvain Petit, Aurélie Cassette
}

\section{To cite this version:}

Nicolas Fleury, Sylvain Petit, Aurélie Cassette. Income inequalities and international trade in goods and services: short and long-run evidence. International Trade Journal, 2012, 26 (3), pp.223-254. 10.1080/08853908.2012.682023 . hal-01831503

\section{HAL Id: hal-01831503 https://hal.science/hal-01831503}

Submitted on 5 Jul 2018

HAL is a multi-disciplinary open access archive for the deposit and dissemination of scientific research documents, whether they are published or not. The documents may come from teaching and research institutions in France or abroad, or from public or private research centers.
L'archive ouverte pluridisciplinaire HAL, est destinée au dépôt et à la diffusion de documents scientifiques de niveau recherche, publiés ou non, émanant des établissements d'enseignement et de recherche français ou étrangers, des laboratoires publics ou privés. 


\title{
Income inequalities and international trade in goods
}

\section{and services: short and long-run evidence ${ }^{\circ}$}

\author{
A. Cassette ${ }^{\mathrm{a}}$, N. Fleury ${ }^{\mathrm{b}}$ and S. Petit $\mathrm{c}^{\text {,* }}$ \\ (Reference: Cassette A., Fleury N. \& S. Petit (2012), «Income inequality and international \\ trade in goods and services: short and long-run evidence», International Trade Journal,
} 26(3):223-254)

\begin{abstract}
In this article, we study short and long-run effects of trade openness in services on wage inequalities between different points of the income distribution. The sample covers 10 OECD countries from 1980 to 2005. We find a differentiated impact of trade in goods compared to trade in services: while trade in goods has a short and a long-run impact on inequalities, trade in services has only long-run effects. We also find that international trade in services enhances inequalities in a stronger way than international trade in goods.
\end{abstract}

JEL classification: C23, F10, D31

\footnotetext{
${ }^{\diamond}$ We would like to thank Etienne Farvaque, Jean-Jacques Nowak, Alain Ayong Le Kama, Jérôme Héricourt, Ali Shah Syed Sarfaraz for comments on a previous version of this paper. We also thank the participants of the "International Trade: A Global Perspective for the $21^{\text {st }}$ Century" conference held in Stoke-On-Trent (United Kingdom) in December 2008.

${ }^{\text {a } E Q U I P P E-U n i v e r s i t e ́ s ~ d e ~ L i l l e, ~ L i l l e ~} 1$ University, F-59655 Villeneuve d'Ascq Cedex, France

${ }^{\mathrm{b}}$ Centre Etudes et Prospective, Groupe Alpha, 20-24 rue Martin Bernard, 75013 Paris, France and EQUIPPEUniversités de Lille, Lille 1 University, F-59655 Villeneuve d'Ascq Cedex, France.

${ }^{\mathrm{c}}$ IDP and EQUIPPE-Universités de Lille, University of Valenciennes, Les Tertiales, rue des cent têtes, 59300 Valenciennes, France

*Corresponding author. E-mail: sylvain.petit@univ-valenciennes.fr
} 


\section{Introduction}

Following the seminal empirical studies of Katz and Murphy (1992) and Lawrence and Slaughter (1993), many papers attempt to estimate the impact of international trade on inequalities. But existing empirical studies focus only on international trade in manufactured goods, while, to our knowledge, no paper examines the specific case of international trade in services. These sectors have traditionally been treated in economics as sectors whose outputs are purely non-tradable. In the last two decades, the telecommunications revolution has changed the basic nature of activities that can be traded: even if some services (like family doctors) are non tradable, others (such as call centers) have become tradable without additional cost, whatever the distance (Head et al., 2009). According to the OECD, services account for more than $20 \%$ of international exchanges. Services are strongly concerned by outsourcing (OECD, 2004; UNCTAD, 2004): multinational firms shift central office (back office) activities away from high wage centers in the OECD countries to back office service centers in places like India. Large shares of services jobs are now "at risk" of being off shored to low-wage countries and even highly-educated workers may face competition from their counterparts in poor countries. The acceleration of international trade (and particularly in services) in the last decades is concomitant to surges in inequality for some countries. International trade in services can thus no longer be discarded and may have contributed to the growth in inequality.

In this article, we re-examine the empirical evidence for the impact of international trade on inequality by using an annual panel data set for 10 northern countries over 26 years. We deal with economic inequality that comprises all disparities in the distribution of economic assets and income among individuals within a country. More precisely, we focus on wage inequalities between high paid workers and low paid workers. Our contribution is two-fold. 
First, we investigate the specific influence of trade openness in services by distinguishing trade in goods from trade in services. Second, the long-term period of our dataset allows us to study the long-run relationship between openness and inequalities. We estimate an Error Correction Model (ECM) to explain the observed short run variations of the dependent variable and to determine the speed at which inequalities come back to long-run equilibrium levels, once they violate the long-run equilibrium relationship ${ }^{1}$.

Results of our empirical investigation are clear-cut. First, we establish a long-run and a shortrun relationship between international trade and inequalities. Second, we show that the relation between international trade and inequalities differs between goods and services: in the long run, trade in commercial services increases inequalities not only between top-income and low-income workers, but also between median income and top-income workers, whereas this latter effect is not verified for the goods sector. Third, in the short-run, international trade in services has no significant impact on inequalities.

\footnotetext{
${ }^{1}$ From an econometric point of view, we find a long run relationship between cointegrated variables: in this case, there exist fundamental economic forces that make the variables move together stochastically over time and their stochastic trends are linked as a long-run equilibrium. In the short run, some shocks lead to a deviation from the long-relationship that is to say to a discrepancy between observed and equilibrium states: the ECM explains the short run consequences of these shocks on the dependent variable and gives the rate at which variables eventually converge to the long run equilibrium. From an economic point of view, introduce differentiation into impacts of short $v s$ long run may notably be justified by the fact that institutions, through national or international regulations may, in the short or the medium run, introduce rigidities of salaries, their evolutions being from a 'sluggish' form (for a recent reference, see Sommer, 2009)
} 


\section{From Theory to Empirics}

Traditional explanations for the link between international trade and inequalities are mainly based on trade in manufactured goods between southern and northern countries. In the wellknown ricardian framework, free trade predicts that the national income increases compared to the autarky situation. In that respect, increase in trade enhances the economic welfare for the members of the society. Nevertheless, some members of the society may suffer from harmful effects, especially the low paid jobs in developed countries. For those who lose from free trade, some compensation may apply, or the expanding industries may offer them a new job. Hence, international trade effects correspond to a positive sum game at the State level. However, the issue of inequalities is missing in the ricardian framework. The effect of international trade on inequalities is predicted by the HOS framework (via the StolperSamuelson theorem) which does not contradict the prediction of Ricardo, concerning the effect of free trade on national income. The seminal two-countries Heckscher-OhlinSamuelson (HOS) framework provides theoretical support for rising inequality: as a country exports the good for which it uses the abundant factor intensively, trade increases the price of this good. This entails an increase in the relative price of the abundant factor in the production of the traded good (a decrease in the remuneration in the scarce factor): for northern countries, this framework predicts a rise in inequalities throught the skill premium (Stolper-Samuelson theorem). Furthermore, new mechanisms have been proposed to explain the effect of international trade on inequality (see the survey by Chusseau et al., 2008): (i) international outsourcing, (ii) capital-skill complementary, (iii) competition-enhancing trade liberalization. The latter is particularly relevant in the case of north-north trade. Nevertheless, most of these explanations are based on theoretical models with manufactured goods. In spite of the liberalization of services and the growing share of these activities in international trade, the effect of international trade in services on inequality has been rarely studied. 
Two approaches are used to analyze the link between trade in services and inequalities. The first approach focuses on the impact of sectoral evolutions on wage inequalities (Askenazy, 2005; Blum, 2008; Anwar, 2010). In an extension of the HOS framework, Askenazy (2005) introduces one southern country which produces manufactured goods and one northern country that produces services and $\mathrm{R} \& \mathrm{D}$, provided by non-skilled and skilled workers respectively. However, in this model, services are supposed to be non-tradable. In this case, the non-skilled workers are protected from international competition. If the R\&D activity has decreasing returns to scale and if households consume a large share of non-traded services, then international trade reduces wage inequalities. Blum (2008) proposes a multi-sector model of international trade to measure the effects of changes in the sectoral composition of an economy. The economy is composed of one tradable sector (manufacturing), and of one nontradable sector (services, wholesale trade and retail trade). Capital is assumed to be complementary to unskilled workers in the manufacturing sector, but complementary to skilled workers in the non-tradable sector. Hence, reallocation of capital from manufacturing to services favors skilled workers relatively to unskilled workers. Similarly, Anwar (2010) show in a 3-sector (agriculture, industry, services) economy how sectoral evolutions may impact inequalities in the short or in the long run. Notably, a decrease in the services sector's fixed costs decreases wage inequality in the short run if the income share of capital in the primary sector is relatively large, but also in the long run, due to the presence of external economies. However, services are always considered as non-tradable in these models. As our objective is to measure the effect of international liberalization in services on inequalities, we implicitly suppose that commercial services are tradable. As a consequence, these models seem not to be appropriate to provide a theoretical framework for our results. The second approach lies on the theoretical model developed by Markusen and Strand (2008) that includes tradable services activities. The standard HOS model is extended by allowing one 
good to geographically fragment into two separate production activities, one in each country. Moreover, one of those two activities is a service activity, and may be allowed to geographically fragment into a more skilled-labor-intensive "headquarters" activity and a less skilled intensive "office" activity. Besides low-skilled workers, two types of skilled workers are assumed: routine medium-skilled workers who can work at a geographic distance from the firm's headquarters, and upper level workers involved in fundamental tasks for the firm. This model predicts that medium-skilled activities, that can be codified and routinized, will tend to migrate to offshore locations, whereas higher skilled activities will stay and expand in highincome countries. As a consequence, international trade in services not only brings higher wage inequalities between skilled and non-skilled workers, but also between high-skilled and medium-skilled workers.

Other arguments provide explanation of the indirect link between trade in services and inequality. According to Jones and Kierzkowski (1990, 2001, 2005), the liberalization of trade in services has led to a surge in outsourcing for low-skilled and medium-skilled activities. In addition, international differentiation on varieties and competition on quality, enhance the demand for skilled labor, and lead to a rise in the skill premium² (Manasse and Turrini, 2001). All these arguments suggest that trade in services increases inequalities between different points of the income distribution.

In the empirical literature, there is much evidence that international trade affect inequalities. For example, using top income share as an inequalities variable, Roine et al. (2009) establish a difference across groups of countries: increased trade is associated with increased top incomes in Anglo-Saxon countries, but not in continental Europe. Among studies

\footnotetext{
${ }^{2}$ Note that this mechanism may apply for both goods and services. Fontagné and Freundenberg (2002) had shown that two-way trades in goods are concerned by the two types of product differentiation: varieties and qualities. For the services, in despite of the difficulty to measure the quality, there is some evidence that these activities are also concerned by these two types of differentiation, as for example in tourism services (Fleischer and Rivlin, 2009).
} 
encompassing countries from all regions of the world, Higgins and Williamson (2002) find little support for the hypothesis that international trade and globalization affect inequalities. Replacing trade openness with tariffs, the relationship between tariffs and inequalities differ according to relative factors endowments. Milanovic and Squire (2005) find that tariff reduction is associated with higher wage inequalities in poorer countries and lower inequalities in richer countries. More precisely, Gourdon et al. (2008) explicitly show that endowments matter in the direction of the relationship between tariffs and inequality: openness is associated with increases in inequality in countries that are relatively wellendowed on capital and on highly skilled workers, while it is associated with decreases in inequality in countries relatively well-endowed on unskilled workers. Recently, Onaran (2011) uses panel data of the manufacturing industry to show a negative but low effect of imports on employment and wages.

This last paragraph shows that empirical papers mainly deals with trade openness in goods. One important contribution of this article is to investigate the specific influence of trade openness in services.

\section{Data}

In this section, we present the variables employed in this article. Table A.1 in the appendix reports the summary statistics and the sources of the data. The aim of this article is to test whether international trade has an impact on inequalities using a balanced panel of ten OECD countries over the 1980-2005 period. Although the size of the cross-section is limited to ten countries $^{3}$, due to data availability, this limitation also ensures that we study countries with comparable factor endowments and technology levels (see Gourdon et al., 2008). In this article, and for availability reasons, we focus on interdecile ratios as inequality indicators

\footnotetext{
3 Australia, Denmark, Finland, France, Germany, Japan, Netherlands, Sweden, United Kingdom and United States.
} 
(INEQ). These indicators are pertinent to study inequalities between different groups of incomes. We use three interdecile ratios: D9/D1, D9/D5, D5/D1, to ensure detailed observation of inequalities. The ratios D9/D1, D9/D5, D5/D1 for wages stand for interdecile ratios $^{4}$ which represents inequalities between different points of the distribution of income. D9/D1 represents a measure of inequalities between higher and lower wages. D9/D5 is a measure of inequalities between higher and medium wages, while D5/D1 corresponds to a measure of inequalities between medium and low wages.

Our main explanatory variable is the scholar openness indicator (total of imports and exports for a country divided by its income). As we focus on developed countries, a positive impact on inequality could be expected. If the mechanisms presented in section 2 apply, we expect a positive impact of openness for goods, for services, and for both sectors altogether, on our three inequality indicators.

Contrary to the existing literature, we do not only examine the impact of the trade in goods on inequality, but also the impact of trade in services. In the CHELEM-CEPII ${ }^{5}$ database, three principal entries of services are distinguished: (i) transport services (flying, shipping and other charges for passengers and for freight); (ii) travel services (restoration services, accommodation services, animation services and services through tour-operators) ; (iii) "other commercial services" (communication services, construction, insurance, financial services, informatics and information services, fees and patents, other services for firms, cultural services, and public administrations). According to Markusen and Strand (2008), the policy

\footnotetext{
${ }^{4}$ The wage deciles are threshold inside the ordered distribution of wages inside a given population: the first decile (D1) represents the threshold under which stands the $10 \%$ of the population who represents the 'lower wages', the $5^{\text {th }}$ decile (the median, D5) represents the threshold under which stands the $50 \%$ of the population who represents the 'lower wages', the $9^{\text {th }}$ decile (D9) represents the threshold below which stands the $10 \%$ of the population who represents the higher wages.

${ }^{5}$ The CEPII's CHELEM-BAL database contains balance of payments statistics for numerous countries and allows several indicators to be calculated (especially on trade openness). This database has been built by the CEPII (French research center in international economics) since the early eighties and gives the possibility to study the specifics of the service sector. The service accounts are displayed at the most detailed level of the IMF fifth manual of the balance of payments.
} 
debate focuses on commercial services. For this reason, we only deal with this last category of services.

International trade may hardly be considered as the only vector of inequality: several control variables must be introduced.

Foreign direct investment. Foreign direct investment corresponds to international financial flows leading to the creation of direct, stable and long links between economies. FDI can be seen as a substitute or complement for the other openness variables. FDI stocks can also be viewed as contributing to the stock of general-purpose technology available in the economy.

Education. We use a variable of skill supply which corresponds to the average years of schooling of the total population aged 25 and over. Education is expected to have a negative impact on inequalities: an increase in education means more abundant skills in the economy, so a decrease in the relative skilled/unskilled wage, and a decrease in the overall income inequality.

Gross domestic product per capita. Gross domestic product per capita may have an impact on inequalities, according to the mechanism initially exposed by Kuznets $(1955)^{6}$. The relationship between inequalities and economic development would follow an inverted Upattern: inequalities within countries have been observed as increasing in the early stage of development, and decreasing in the latter. There is no consensus on these results, especially since the work by Piketty (2001) and the new literature on rising inequalities (Atkinson, 2003). If the relationship between development and inequalities is now an 'inverted' Kuznets curve, we expect a positive relationship for the sample of countries in our estimations.

\footnotetext{
${ }^{6}$ Another advantage of the GDP per capita variable is to make sure that inward FDI does not merely pick up the impact of the level of economic development on inequality.
} 
Inflation. We include the inflation rate to check for the macroeconomic environment which is likely to affect income distribution. Inflation erodes real wages and disproportionately affects those within the bottom percentiles of income distribution, thus increasing inequalities.

Technological progress. Technological development is proxied by the growth rate in the share of information and communication technology (ICT) capital in the total capital stock. This ICT capital stock has risen rapidly over the past 20 years. This technology is interconnected with globalization, as international trade in services is permitted by development of such technology. Technical progress is often seen to be skill biased, and may be a complement to international trade to explain rising inequalities (see for example the survey by Chusseau et al., 2008).

Institutional context on the labor market. We introduce several variables reflecting labor market characteristics and the influence of trade unions on wage setting. The trade union density is calculated as the total union membership (less self-employed and retired) weighted by the total dependent labor force. We could expect that a country with a greater share of people engaged in trade unions has lower wage inequalities. We use two indicators of involvement in wage setting, one for the trade unions (Confederal involvement) and one for the government (Government involvement). We could expect that both trade unions and governments want to limit inequalities. We also consider the bargaining level at which wages are determined. We expect that the income distribution tends towards more inequalities under plant-level wage setting (the variable takes a value equal to 1 ) than under central wage setting with sanctions (the variable takes a value equal to 4). Finally, we introduce the Herfindahl index of union concentration across all confederations. The higher the concentration the greater their margin of maneuver and the greater their ability to limit inequalities. 


\section{Empirical specification}

As time series dominate the cross section, we need to check the stationarity of our variables. Im, Pesaran and Shin (2003) have developed panel-based unit root tests which depend on the mean of the individual Dickey-Fuller t-statistics of each unit in the panel. It has been shown that panel unit root tests are more powerful than unit root tests applied to individual series because the time series dimension is enhanced by the number of cross sections (Baltagi, 2001). This test assumes that all series are non-stationary under the null hypothesis. Several procedures have been advocated to test for a unit root with panel data techniques. The main difference between them concerns assumptions about the heterogeneity of the data-generating model. It appears that heterogeneity has first been introduced via fixed effects and then via the autoregressive dynamic structures $\rho_{\mathrm{i}}$ :

$$
\Delta \mathrm{y}_{\mathrm{i} ; \mathrm{t}}=\alpha_{\mathrm{i}}+\delta_{\mathrm{i}} \mathrm{t}+\theta_{\mathrm{t}}+\rho_{\mathrm{i}} \mathrm{y}_{\mathrm{i}, \mathrm{t}-1}+\varsigma_{\mathrm{i} ; \mathrm{t}}
$$

Im, Pesaran and Shin (2003) study the small sample properties of unit root tests in panels with heterogeneous dynamics. From results displayed in table A.2, most of our variables of interest are difference stationary (our three inequalities variables, our three openness variables, GDP per capita and the stock of inward FDI): in level, the null hypothesis of a unit root is never rejected for these variables but rejection is accepted at the $1 \%$ level when the variables are in first difference. However, the education variable, the inflation rate, the technological progress proxy and institutional variables are level stationary. Rejection of the null hypothesis of a unit root is accepted at the $1 \%$ level for these variables expressed both in level and in first difference This implies that they are short-run determinants of inequalities, but without longrun effect. 
Due to the presence of unit roots in our main variables, panel cointegration tests are conducted to see whether there is a long-run equilibrium between our variables. We use Pedroni's (1999) cointegration tests as it allows for considerable heterogeneity in fixed effects, individual deterministic trends and slope coefficients of the cointegrating vectors. Under the null hypothesis of no cointegration, the residual is also integrated of order one $\left(\rho_{\mathrm{i}}=\right.$ $1, \forall i)$ :

$$
\mathrm{y}_{\mathrm{i} ; \mathrm{t}}=\alpha_{\mathrm{i}}+\delta_{\mathrm{i} ; \mathrm{t}}+\gamma_{\mathrm{t}}+\beta_{1} \mathrm{x}_{\mathrm{i} ; \mathrm{t}}+\ldots+\beta_{\mathrm{Mi}} \mathrm{x}_{\mathrm{mi}, \mathrm{t}}+\varepsilon_{\mathrm{i} ; \mathrm{t}} \text { with } \varepsilon_{\mathrm{i} ; \mathrm{t}}=\rho_{\mathrm{i}} \varepsilon_{\mathrm{i} ; \mathrm{t}-1}+\mathrm{u}_{\mathrm{i} ; \mathrm{t}}
$$

These tests run individual cointegrating regressions for each member, collect estimated residuals and compute either pooled panel root test, or group mean unit root test. In each case, rejection of the null hypothesis means that the variables under consideration are cointegrated. For a sufficient time dimension $(\mathrm{T}>20)$, these tests have a standard normal distribution and give the same quality of results. If some of our variables are cointegrated, there is a risk of fallacious regression using standard estimation techniques. Results provided in table A.3 indicate that we cannot accept the null hypothesis of no cointegration between each independent variable and the inequalities variable. Independent variables are cointegrated between each other and must not be included simultaneously: we will estimate the long-run relationship between inequalities and each openness variable separately ${ }^{7}$. However, the inward stock of FDI and the GDP per capita are not cointegrated, so we can introduce them in the same cointegration equation.

When variables are cointegrated, we have to estimate the long-run relationship between them. A fallacious regression might be obtained if we use standard estimation techniques. Although the OLS regression is super-consistent, it is also asymptotically biased in general (Pedroni,

\footnotetext{
${ }^{7}$ For a set of $\mathrm{n}$ variables, there can be up to $\mathrm{n}-1$ independent cointegrating vectors (Harris, 1995). If explanatory variables were cointegrated among them, there would more than $n-1$ cointegrating vectors. So we do not put explanatory variables that are cointegrated between them simultaneously in the regression.
} 
2000 ; Kao and Chen, 1995). While this is a second order effect for the conventional single series estimator, for panels, as $N$ grows large, the effect has the potential to become first order. The reason is that the nonstationary regressors are endogenously determined. Efficient methods like Fully Modified (FMOLS) and Dynamic OLS (DOLS) are required. Kao and Chiang (2000) study the finite sample properties of the OLS, FMOLS and DOLS estimators in cointegrated regressions. They show that the OLS estimator has a non-negligible bias in a finite sample, and that the FMOLS estimator does not improve the OLS in general. Finally, the DOLS estimator outperforms the other estimators, particularly in terms of mean-bias. We thus choose this method to estimate the following cointegration relationship. The cointegration equation employed in this paper is the following:

$$
y_{i, t}=x_{i ; t} \beta+\sum_{s=-\infty}^{+\infty} \Delta x_{i, t-s} \delta_{i ; t-s}+\varepsilon_{i ; t} \quad \text { for } i=1, \ldots, N ; t=1, \ldots, T
$$

Where $\beta$ is the cointegrating coefficient. DOLS uses the past and future values of the variation of the explanatory variable as additional regressors. It allows for heterogeneity across countries (through individual-specific time trends, individual-specific fixed effects and timespecific effects).

In a second step, we estimate long and short-run relationships by using a panel-based error correction model $(\mathrm{ECM})^{8}$. It permits us to establish how the short run varies from the long-run relationship, and more precisely, how the economy adjusts itself to disturbances over time. The specification of our Error Correction Model is:

$$
\begin{aligned}
\Delta I N E Q_{i ; t}= & \alpha \Delta I N E Q_{i ; t-1}+\theta \Delta \text { Openness trade } e_{i ; t}+\delta \Delta \text { Openness trade } e_{i ; t-1} \\
& +\eta \text { Error Correction Term } \text { Tert-1 }_{i ;}+\varphi X_{i ; t-1}+\psi_{t}
\end{aligned}
$$

$I N E Q$ represents our dependent variable, the degree of inequality, Openness trade is our main explainatory variable and $X$ is a vector of control variables. The time-specific effect, $\psi_{t}$, is

\footnotetext{
${ }^{8}$ For a recent reference on cointegration and ECM with panel data, see Francis et al. (2007). See also Kale (2001) for an application of cointegration and ECM on longitudinal data.
} 
included to capture aggregate shocks, which can appear in any year. The error correction term comes from the residuals of the long-run relationship estimated using the DOLS method. The coefficient on the error correction term, $\eta$, gives the adjustment rate at which the gap between inequalities and the variable of interest is closed. If $\eta$ is negative and significant, the model is an ECM.

Since this is a dynamic panel data model, an instrumental variable estimator must be used to deal with the correlation between the error term and the lagged dependent variables. First, we implement heteroskedastic and autocorrelation consistent (HAC) standard errors, because the Wooldridge test (2002) for serial correlation in the idiosyncratic errors of a linear panel-data model implies the existence of arbitrary serial correlation. Second, the model can be estimated using a specific dynamic panel data methodology. However, our data set contains a small number of observations in the cross section (10 countries) and a relatively large time dimension (26 years): in this case, Judson and Owen (1999) show that the LSDVC (Least Square Dummy Variable Corrected) estimator, suggested by Kiviet (1995) outperforms alternative estimators like the GMM-system estimator developed by Blundell and Bond (1998).

\section{Long-run equilibrium relationship between international trade and inequality}

Here, we examine the long-run equilibrium relationship between international trade and inequalities, using the Dynamic OLS estimator (DOLS) ${ }^{9}$. Table 1 gives the mean group panel DOLS estimates for the full sample over the period 1980-2005.

\footnotetext{
${ }^{9}$ Given the annual data, the lags on the DOLS were taken to be first-order.
} 
Table 1. DOLS estimates with year dummies

\begin{tabular}{ll|l|l} 
& $\mathrm{D} 9 / \mathrm{D} 1$ & $\mathrm{D} 9 / \mathrm{D} 5$ & $\mathrm{D} 5 / \mathrm{D} 1$ \\
\hline Total trade & $0.01^{* * *}$ & 0.0007 & $0.008^{* * *}$ \\
openness & $(6.73)$ & $(0.83)$ & $(8.23)$ \\
\hline Trade openness in & $0.007^{* *}$ & -0.001 & $0.005^{* * *}$ \\
goods & $(2.29)$ & $(-1.24)$ & $(4.45)$ \\
\hline Trade openness in & $0.06^{* * *}$ & $0.007^{* * *}$ & $0.03^{* * *}$ \\
services & $(6.77)$ & $(2.22)$ & $(5.88)$ \\
\hline FDI stocks & $0.005^{* * *}$ & $0.001^{* * *}$ & $0.004^{* * *}$ \\
& $(4.92)$ & $(4.02)$ & $(8.52)$ \\
GDP per capita & $0.006^{* * *}$ & 0.001 & $0.001^{* *}$ \\
& $(3.25)$ & $(1.22)$ & $(2.04)$ \\
\hline
\end{tabular}

Notes: t-Student in parentheses. $*$ significant at $10 \%, * *$ significant at $5 \%$, *** significant at $1 \%$ level.

First, total international trade and trade in goods have similar effects on inequalities. Coefficients have the same sign, size and significance. International trade exhibits a significant positive long-run effect on D9/D1 and D5/D1, whereas the coefficient of the D9/D5 variable is positive but not significant. This result can be linked to traditional HOS predictions. Countries of our sample are more abundant in high-skilled and medium-skilled labor relatively to other countries, and especially southern countries. International trade increases top incomes relatively to low incomes.

Second, international trade in commercial services has a significant positive impact on each of our three inequality indicators at the sample level. Contrary to international trade in goods, international trade in services increases inequalities between top incomes and median incomes (D9/D5). In the long run, trade in services increases the gap between low paid workers and the other points of the income distribution but also between median incomes and top incomes. Markusen and Strand's (2008) theoretical work provides a potential explanation for this result. As low-skilled activities, medium-skilled activities tend to be offshore, whereas highskilled activities stay in the domestic country. These kinds of services (financial services, patents and fees, insurance services, information services, or business services) are mainly traded between northern countries and concern highly qualified workers. In this case, we can 
also use the argumentation of Manasse and Turrini (2001): international differentiation on varieties and competition on quality lead to a rise in the skill premium. In addition, the liberalization of trade in services has led to a surge in outsourcing (Jones and Kierzkowski, 1999, 2001, and 2005), for low-skilled and medium-skilled activities, which could lead to a rise in inequalities in the home country.

Concerning the other variables, as FDI stocks and GDP per capita are not cointegrated, we introduce them simultaneously in the cointegration equation. As expected, there is a positive and highly significant long-run relationship between FDI stocks and inequalities. In developed countries, inward FDI is mainly concentrated in the tertiary sector (UNCTAD, 2008). FDI stocks variable is then a complement to international trade, especially to trade in services, as the variable of FDI stocks also increases D9/D5. We also find a positive and significant long-run relationship between GDP per capita and income inequalities, except on D9/D5.

\section{ECM Results}

Tables 2 and 3 display the results for the Error Correction Model estimated using the IV method. An important issue using the IV method is the validity of instruments. We provide results from Kleibergen-Paap test and Hansen J-test to deal with this question. The former is an underidentification test while the latter is an overidentification test. It is often stated that there must be at least as many instruments as endogenous variables. On the one hand, underidentification is observed when there are more endogenous regressors than the number of valid instruments. When Kleibergen-Paap test statistic passes the critical value of 10 , the null of underidentification can be rejected. On the other hand, when there are too many, the instruments can overfit endogenous variables, failing to expunge their endogenous 
components and biasing coefficient estimates. Hansen-J-test determines if the instruments are uncorrelated with the error term. High values and high probability values respectively for the Kleibergen-Paap statistics and for the Hansen $J$-tests ${ }^{10}$ do not call into question the validity of the results of any of the regressions. The same results are obtained using the LSDVC estimator (table A.2 in appendix). We check for potential multicollinearity between regressors: for all our variables, the Variance Inflation Factor is lower than 7. These results confirm that our variables do not suffer from any multicollinearity problems.

\footnotetext{
${ }^{10}$ For LSDVC estimations, the test of over-identifying restrictions comes from the first-stage regression results.
} 
Table 2. ECM results (openness variables)

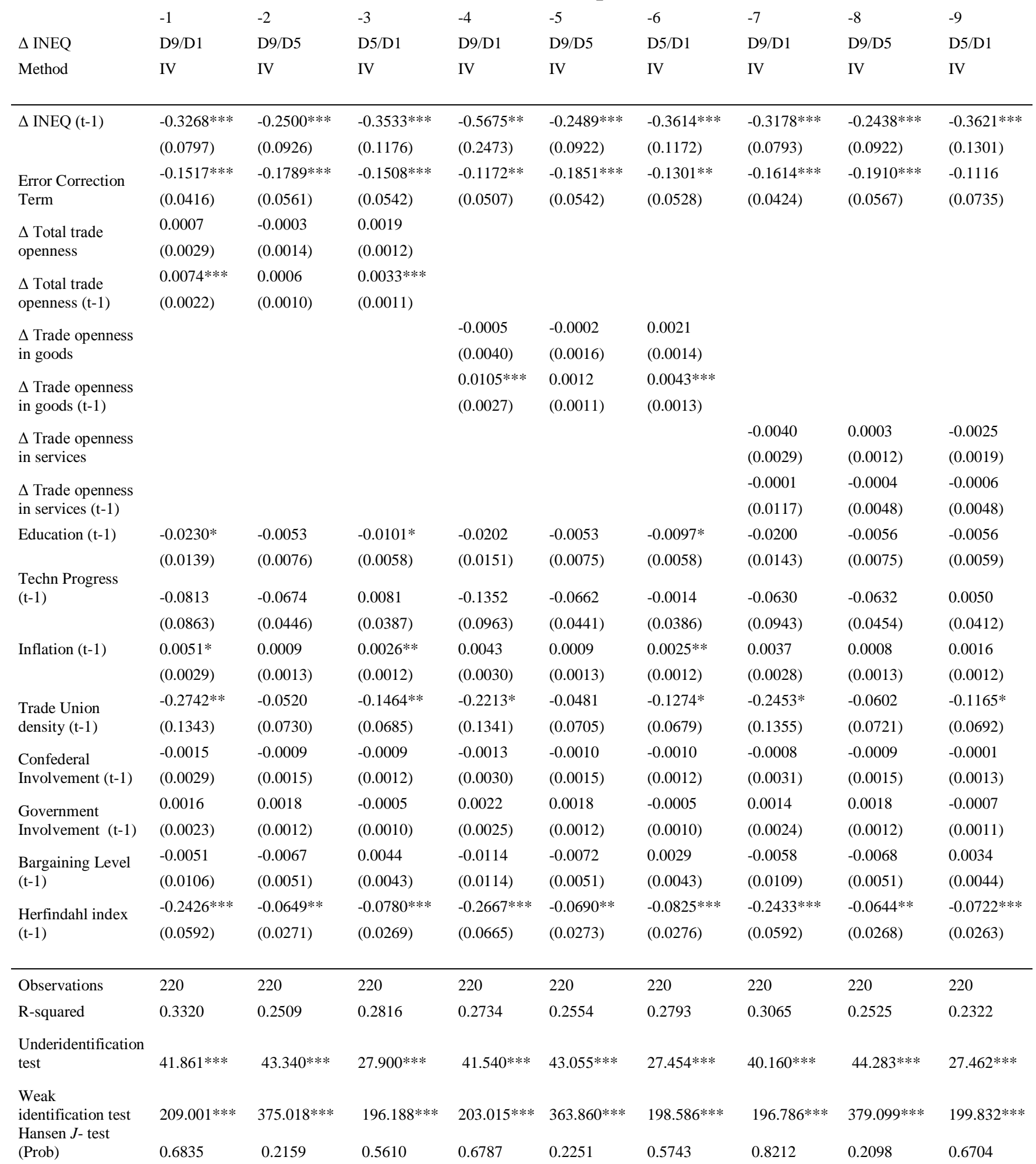

Notes: Estimates include year dummies. Robust standard errors in parentheses. * significant at $10 \%$, $* *$ significant at $5 \%, * * *$ significant at $1 \%$ level. 
Table 3. ECM results (other variables)

\begin{tabular}{|c|c|c|c|c|c|c|}
\hline & -1 & -2 & -3 & -4 & -5 & -6 \\
\hline$\Delta$ INEQ & D9/D1 & D9/D1 & D9/D5 & D9/D5 & D5/D1 & D5/D1 \\
\hline Method & LSDVC & IV & LSDVC & IV & LSDVC & IV \\
\hline \multirow[t]{2}{*}{$\Delta \operatorname{INEQ}(\mathrm{t}-1)$} & $-0.1858 * *$ & $-0.2934 * * *$ & $-0.1947 * *$ & $-0.2327 * *$ & $-0.2114 * * *$ & $-0.3565 * * *$ \\
\hline & $(0.0734)$ & $(0.0819)$ & $(0.0818)$ & $(0.0944)$ & $(0.0754)$ & $(0.1292)$ \\
\hline Error Correction & $-0.1268 * * *$ & $-0.1339 * * *$ & $-0.1791 * * *$ & $-0.2040 * * *$ & -0.0417 & -0.0073 \\
\hline Term & $(0.0438)$ & $(0.0423)$ & $(0.0612)$ & $(0.0547)$ & $(0.0474)$ & $(0.0699)$ \\
\hline \multirow[t]{2}{*}{$\Delta$ FDI stocks } & 0.0023 & 0.0021 & 0.0013 & $0.0013 *$ & -0.0002 & -0.0003 \\
\hline & $(0.0024)$ & $(0.0014)$ & $(0.0010)$ & $(0.0007)$ & $(0.0011)$ & $(0.0007)$ \\
\hline$\Delta$ FDI stocks & 0.0013 & 0.0011 & -0.0003 & -0.0004 & 0.0006 & 0.0007 \\
\hline$(\mathrm{t}-1)$ & $(0.0020)$ & $(0.0019)$ & $(0.0009)$ & $(0.0009)$ & $(0.0009)$ & $(0.0010)$ \\
\hline \multirow[t]{2}{*}{$\Delta$ GDP per capita } & 0.0024 & 0.0020 & 0.0005 & 0.0006 & 0.0011 & 0.0008 \\
\hline & $(0.0022)$ & $(0.0024)$ & $(0.0009)$ & $(0.0012)$ & $(0.0010)$ & $(0.0011)$ \\
\hline$\Delta$ GDP per capita & -0.0042 & $-0.0046^{* *}$ & -0.0007 & -0.0009 & -0.0018 & $-0.0019^{*}$ \\
\hline$(\mathrm{t}-1)$ & $(0.0029)$ & $(0.0023)$ & $(0.0013)$ & $(0.0010)$ & $(0.0013)$ & $(0.0010)$ \\
\hline \multirow[t]{2}{*}{ Education (t-1) } & -0.0111 & -0.0183 & -0.0076 & -0.0076 & 0.0021 & -0.0016 \\
\hline & $(0.0131)$ & $(0.0142)$ & $(0.0051)$ & $(0.0074)$ & $(0.0062)$ & $(0.0061)$ \\
\hline Techn Progress & -0.0489 & -0.0615 & $-0.0570^{*}$ & -0.0567 & 0.0054 & 0.0030 \\
\hline$(\mathrm{t}-1)$ & $(0.0758)$ & $(0.0935)$ & $(0.0344)$ & $(0.0435)$ & $(0.0326)$ & $(0.0421)$ \\
\hline \multirow[t]{2}{*}{ Inflation (t-1) } & 0.0023 & 0.0030 & 0.0003 & 0.0006 & 0.0011 & 0.0012 \\
\hline & $(0.0041)$ & $(0.0028)$ & $(0.0017)$ & $(0.0013)$ & $(0.0018)$ & $(0.0013)$ \\
\hline Trade Union & -0.1459 & $-0.2794 *$ & -0.0549 & -0.0881 & -0.0721 & $-0.1204 *$ \\
\hline density (t-1) & $(0.1707)$ & $(0.1427)$ & $(0.0801)$ & $(0.0734)$ & $(0.0717)$ & $(0.0708)$ \\
\hline Confederal & 0.0026 & 0.0001 & -0.0005 & -0.0009 & 0.0019 & 0.0011 \\
\hline Involvement (t-1) & $(0.0028)$ & $(0.0031)$ & $(0.0011)$ & $(0.0014)$ & $(0.0013)$ & $(0.0013)$ \\
\hline Government & -0.0021 & 0.0006 & 0.0013 & 0.0019 & $-0.0022 * *$ & -0.0014 \\
\hline Involvement (t-1) & $(0.0022)$ & $(0.0023)$ & $(0.0010)$ & $(0.0012)$ & $(0.0010)$ & $(0.0011)$ \\
\hline Bargaining Level & $-0.0123^{*}$ & -0.0070 & $-0.0081 * * *$ & -0.0064 & 0.0003 & 0.0014 \\
\hline$(\mathrm{t}-1)$ & $(0.0065)$ & $(0.0109)$ & $(0.0030)$ & $(0.0051)$ & $(0.0026)$ & $(0.0045)$ \\
\hline Herfindahl index & $-0.2170^{*}$ & $-0.2290 * * *$ & -0.0599 & $-0.0613^{* *}$ & -0.0548 & $-0.0463^{*}$ \\
\hline$(\mathrm{t}-1)$ & $(0.1134)$ & $(0.0628)$ & $(0.0467)$ & $(0.0264)$ & $(0.0491)$ & $(0.0262)$ \\
\hline Observations & 240 & 220 & 240 & 220 & 240 & 220 \\
\hline R-squared & I & 0.3023 & l & 0.2645 & l & 0.2214 \\
\hline Underidentification test & I & $41.614 * * *$ & I & $44.114 * * *$ & l & $29.709 * * *$ \\
\hline Weak identification test & I & $193.171 * * *$ & I & $373.030 * * *$ & I & $240.554 * * *$ \\
\hline Hansen $J$-test (Prob) & 0.9845 & 0.7472 & 0.9891 & 0.2299 & 0.9961 & 0.5866 \\
\hline
\end{tabular}

Notes: Estimates include year dummies. Robust standard errors in parentheses. * significant at $10 \%$, ** significant at $5 \%, * * *$ significant at $1 \%$ level.

We first note that the lagged first difference endogenous variable is always very significant and takes a value between -0.24 and -0.56 in all specifications, which confirms autoregressive specification (4). The error correction coefficients have statistically significant negative signs in all regressions. Furthermore, the statistical significance of the error correction terms 
implies that, if there are deviations from the long-run equilibrium, short-run adjustments will be made to the dependent variable to re-establish the long run equilibrium.

The impact of openness variables is only significant with the lagged variables, which indicates that increased openness always takes one period to have an impact on inequality. The first set of regressions introduces the aggregate openness variable commonly used in the literature to study the link between international trade and inequality. It shows that total international trade has a significant and positive short-run impact both on D9/D1 and D5/D1 (a positive relationship has been established in the long run in the previous section). As our sample is composed of developed countries, several explanations can be provided (that we developed in the previous section), but at this aggregate level, it is not possible to define which one dominates. Consequently it seems particularly relevant to look at a more disaggregated level.

The second set of regressions confirms this result for the goods sectors. Growing north-south trade is very likely to enhance inequalities. It could confirm the HOS prediction as in the previous section. An increase in the trade in goods has a short-run impact on inequalities between top incomes and low incomes, and also between median incomes and low incomes. The results suggest that when trade openness increases in a developed country, income inequalities will rise in the following year and will persist in the long run.

The third set of regressions shows that whatever the inequalities indicator, we observe no significant influence of trade in services on inequalities in the short run (table 2, columns 7 to 9). All the theoretical mechanisms of international trade in services and inequalities (Markusen and Strand, 2008; Manasse and Turrini, 2001; Jones and Kierzkowski, 1999, 2001, and 2005) seem to be invalid in the short run. How to explain the absence of effect in the short run? From a theoretical point of view, it is well known that short run effect can be substantially different from long run effect (see Chao and Yu, 1997; Das, 2002; Anwar, 
2010). From an empirical point of view, our results corroborate the presence of dynamic or cumulative effects of the trade of services through the years. Due to the acceleration of international trade in services in the 2000's, the trend of inequality is predicted to become sharper in developed countries in the following years, ceteris paribus

Table 3 gives the results when the main variables of interest are the stock of inward FDI and the GDP per capita. Both variables have long-run effects on inequalities. However in the short run, the stock of FDI has no significant effect on inequalities. As for GDP per capita, significant effects are only observed using the IV method: when GDP per capita increases in period $t$, inequalities between top incomes and low incomes (and between median incomes and low incomes) decrease in the following period. However in the long run, there is a rise in inequalities. It seems that the effect differs between the long run and the short run.

For the control variables, note that sizes and significances do not vary between columns, which indicates that our results are robust whatever the method used. The education variable has the expected negative effect on inequality, but the coefficient is not always significant. This result is not surprising, as it is likely that it takes times for education to produce effects. Concerning the labor market characteristics, the coefficient of the trade union density and the Herfindahl index variables are significant and negative as expected. Finally, the inflation variable has a positive impact on inequality, but not always significant and the coefficient related to technical progress sometimes has a negative and significant sign.

\section{Conclusion}

The objective of the article was to distinguish the effect of international trade in goods and services on inequalities to determine if the recent rise in international trade in services explains growing inequalities in OECD countries. Short and long-run estimations have been 
performed and give the following results. First, we show that the relationship between international trade and inequalities differs between goods and services: in the long run, trade in commercial services increases inequalities not only between top incomes and low incomes, but also between top incomes and median incomes, whereas this latter effect is not verified for the goods sector. These results indicate that it is relevant to take into account the specific case of services. Second, in the short run, international trade in services has no significant impact on inequalities. This indicates that it is appropriate to distinguish short run and long run effects.

Finally, the main results of the article suggest that not only low-income workers, but also median-income workers in the services sector, are threatened by international trade to experience rising inequalities compared to top-income workers, in developed economies. As wage inequality is a relative measure of the labour incomes between different groups, this result should be qualified. Indeed, our paper studies the impact of international trade on the relative positions of high-income workers and low-income workers, between high-income workers and median income workers and between median income workers and low-income workers. Hence, in terms of relative advantages, low-income and medium-income workers lose from the trade in services compared to high incomes workers. But it does not mean that in terms of absolute advantage, the situation of these particular groups worsens: indeed, their situation may simply worsen more than that of the high-income group, or experience less improvement than that of the high-income group of workers. The harmful (relative) effects of trade in services on wage inequality highlighted in this article suggest that developed countries need to develop high-tech sectors (which require high-skilled workers) and to pursue higher education. Otherwise, as international trade of services accelerated in the 
2000 's, the trend of the rising inequalities observed in northern countries could be reinforced in the next decades

\section{$\underline{\text { References }}$}

Anwar, S. (2010) Wage Inequality, Increased Competition and Trade Liberalization: Short Run vs. Long Run, Review of International Economics, 18, 574-581.

Atkinson, A.B. (2003) Income Inequality in OECD countries: Data and Explanations, CESifo working paper No. 881.

Askenazy, P. (2005) Trade, services and wage inequality, Oxford Economic Papers, 57, 674692.

Baltagi, B.H. (2001) Econometric Analysis of Panel Data, 2nd ed. Chichester, UK: John Wiley.

Barro, R.J. and Lee, J.W. (2001) International Data on Educational Attainment: Updates and Implications, Oxford Economics Papers, 53, 541-563

Blum, B. (2008) Trade, Technology, and the Rise of the Service Sector: The Effects on US Wage Inequality, Journal of International Economics, 74, 441-458.

Chao, C-C. and Yu, E.SH. (1997) Trade Liberalization in Oligopolistic Competition with Unemployment: A General Equilibrium Analysis, Canadian Journal of Economics, 30, 479-496.

Chusseau, N., Dumont, M. and Hellier, J. (2008) Explaining Rising Inequality: Skill-Biased Technical Change and North-South Trade, Journal of Economic Surveys, 22, 409-457.

Das, S.P. (2002) Foreign Direct Investment and the Relative Wage in a Developing Economy, Journal of Development Economics, 67, 55-77.

Fleisher, A. and Rivlin, J. (2009) Quality, Quantity and Duration Decisions in Household Demand for Vacations, Tourism Economics, 18, 513-530 
Fontagné, L. and Freudenberg, M. (2002) Long-term Trends in Intra-Industry Trade, in Lloyd P.J et Lee H-H. (2002), Frontiers of research in Intra-Industry Trade, Palgrave ed., London: Macmillan Press.

Francis, B., Iyare, S.O., and Lorde, T. (2007) Agricultural Export-Diversification and Economic Growth in Caribbean Countries: Cointegration and Error-Correction Models, International Trade Journal, 21, 229-256.

Golden, M. Wallerstein, M. and Lange P. (2006) Union Centralization Among Advanced Industrial Societies: An Empirical Study of Organisation for Economic Co-operation and Development (OECD) Countries, 1950-2000, Inter-university Consortium for Political and Social Research

Gourdon, J., Maystre, N. and de Melo, J. (2008) Openness, inequality and poverty: Endowments matter, Journal of International trade and Economic Development, 17, 343 378.

Harris, R. I. D. (1995), Using Cointegration Analysis in Econometric Modelling, Prentice Hall Publishing, Essex England

Head, K., Mayer, T. and Ries J. (2009) How remote is the offshoring threat?, European Economic Review, 53, 429-444.

Higgins, M. and Williamson, J.G. (2002) Explaining Inequality in the World round: cohort size, Kuznets curves and openness, Southeast Asian Studies, 40, 268-302.

Im, K.S., Pesaran, M.H. and Shin, Y. (2003) Testing for Unit Roots in Heterogeneous Panels, Journal of Econometrics, 115, 53-74.

Jones R. W. and Kierzkowski, H. (1990) The role of services in production and international trade: A theoretical framework, in The Political Economy of International Trade, R. W. Jones and Krueger A. (eds), Oxford, Basil Blackwell. 
Jones, R.W. and Kierzkowski, H. (2001) A framework for fragmentation, in Fragmentation. New Production Patterns in the World Economy, Arndt, S.W. and Kierzkowski H. (eds.), Oxford University Press.

Jones, R.W and Kierzkowski, H. (2005) International Fragmentation and the New Economic Geography, North American Journal of Economics and Finance, 16, 1-10.

Judson, R.A. and Owen, A.L. (1999) Estimating Dynamic Panel Data Models: A Guide for Macroeconomists, Economics Letters, 65, 9-15.

Kale, P. (2001) Turkey's Trade Balance in the Short and the Long Run: Error Correction Modelling and Cointegration, International Trade Journal, 25, 27-56.

Kao, C. and Chen, B. (1995) On the Estimation and Inference of a Cointegrated Regression in Panel Data When the Cross-section and Time-series Dimensions Are Comparable in Magnitude, Working paper, Department of Economics, Syracuse University

Kao, C. and Chiang, M-H. (2000) On the Estimation and Inference of a Cointegrated Regression in Panel Data, Advances in Econometrics, 15,179-222.

Katz, L.F. and Murphy, K., (1992) Changes in relative wages, 1963-1987: supply and demand factors, Quarterly Journal of Economics, 107, 36-78.

Kiviet, J.F. (1995) On bias, Inconsistency and efficiency of Various Estimators in Dynamic Panel Data Models, Journal of Econometrics, 68, 53-78.

Kuznets, S. (1955) Economic growth and income inequality, The American Economic Review, 45, 1-28.

Lawrence, R. and Slaughter, M.J. (1993) International Trade and American Wages in the 1980s: Giant Sucking Sound or Small Hiccup? Brooking Papers on Economic Activity: Microeconomics, 2, 161-226. 
Markusen J. and Strand, B. (2008) Offshoring of Business Services in Small Open Economies: Toward a General-Equilibrium Modeling Approach, Journal of Industry, Competition and Trade, 8, 231-46.

Manasse, P. and Turrini, A. (2001) Trade, wages, and 'superstars', Journal of International Economics, 54, 97-117.

Milanovic, B. and Squire, L. (2005) Does tariff liberalization increase wage inequality? Some empirical evidence, NBER working paper No 11046.

OECD (2004) Potential offshoring of ICT-intensive using occupations, Directorate for Science, Technology and Industry - Committee for Information, Computer and Communications Policy, OECD.

Onaran, Ö. (2011) The Effects of Import Penetration on Labour Market Outcomes: the Case of Austrian Manufacturing Industry, International Trade Journal, 25, 163-204

Pedroni, P. (1999) Critical Values for cointegration tests in heterogeneous panels with multiple regressors, Oxford Bulletin of Economics and Statistics, 61, 653-670.

Pedroni P. (2000) Fully Modified OLS for Heterogeneous Cointegrated Panels, Advances in Econometrics, 15, 93-130.

Piketty, T. (2001), Les hauts revenus en France au 20ème siècle, Inégalités et Redistributions: 1901-1998, Grasset, Paris.

Roine, J., Vlachos, J. and Waldenström, D. (2009) The long-run determinants of inequality: What can we learn from top income data?, Journal of Public Economics, 93, 974-988.

Sommer, M. (2009) Why Are Japanese Wages So Sluggish?, IMF Working Papers No 09/97, International Monetary Fund.

UNCTAD (2004) The World Investment Report 2004: The Shift Towards Services, United Nations.

UNCTAD (2008) World Investment Report, United Nations.

Wooldridge, J. (2002) Econometric Analysis of Cross Section and Panel Data, MIT Press. 


\section{Appendix}

Table A.1: Data Sources and summary statistics

\begin{tabular}{|c|c|c|c|c|}
\hline variable & Source & Name and definition & Mean & Std.Dev \\
\hline \multirow{3}{*}{$\begin{array}{l}\text { Inequality } \\
\text { variable }\end{array}$} & \multirow[t]{3}{*}{ OECD } & D9/D1 & 2.9362 & 0.61767 \\
\hline & & D9/D5 & 1.786 & 0.16902 \\
\hline & & D5/D1 & 1.6272 & 0.19610 \\
\hline \multirow{3}{*}{$\begin{array}{l}\text { International } \\
\text { trade variables }\end{array}$} & \multirow[t]{3}{*}{ CHELEM-CEPII } & Total trade openness & 27.437 & 13.021 \\
\hline & & Trade openness in goods & 21.558 & 10.276 \\
\hline & & $\begin{array}{l}\text { Trade openness in } \\
\text { services }\end{array}$ & 2.5875 & 1.6800 \\
\hline $\begin{array}{l}\text { Foreign Direct } \\
\text { Investment } \\
\text { stocks }\end{array}$ & $\begin{array}{l}\text { IMF-International Financial } \\
\text { Statistics }\end{array}$ & FDI stocks (in \% GDP) & 14.921 & 14.530 \\
\hline $\begin{array}{l}\text { Gross Domestic } \\
\text { Product per } \\
\text { capita }\end{array}$ & $\begin{array}{l}\text { IMF-International Financial } \\
\text { Statistics }\end{array}$ & GDP per capita $(\$ 1000$ s) & 20.399 & 7.3802 \\
\hline Inflation & $\begin{array}{l}\text { CHELEM IMF-International } \\
\text { Financial Statistics }\end{array}$ & Inflation rate & 3.6309 & 3.2226 \\
\hline $\begin{array}{l}\text { Education } \\
\text { variable }\end{array}$ & $\begin{array}{l}\text { Barro, R.J. and Lee, J.W. } \\
\text { (2001) }\end{array}$ & $\begin{array}{l}\text { Education: Average years } \\
\text { of schooling of the total } \\
\text { population aged } 25 \text { and } \\
\text { over }\end{array}$ & 9.5845 & 1.2377 \\
\hline $\begin{array}{l}\text { Technological } \\
\text { Progress }\end{array}$ & EUKLEMS (2007) & $\begin{array}{l}\text { Techn Progress: Growth } \\
\text { rate in the share of } \\
\text { information and } \\
\text { communication } \\
\text { technology capital in the } \\
\text { total capital stock }\end{array}$ & 3.3625 & 2.5743 \\
\hline \multirow[t]{5}{*}{$\begin{array}{l}\text { Labor market } \\
\text { characteristics }\end{array}$} & \multirow{5}{*}{$\begin{array}{l}\text { Golden M., Wallerstein M. } \\
\text { and Lange P. (2006) } \\
\text { Union Centralization Among } \\
\text { Advanced Industrial Societies: } \\
\text { An Empirical Study of } \\
\text { Organisation for Economic } \\
\text { Co-operation and } \\
\text { Development (OECD) } \\
\text { Countries, 1950-2000 }\end{array}$} & Trade Union Density & 0.38618 & 0.23259 \\
\hline & & $\begin{array}{l}\text { Confederal involvement in } \\
\text { wage-setting }\end{array}$ & 3.6231 & 2.7390 \\
\hline & & $\begin{array}{l}\text { Government involvement in } \\
\text { wage-setting }\end{array}$ & 5.3385 & 3.2515 \\
\hline & & $\begin{array}{l}\text { Bargaining level at which } \\
\text { wages are determined }\end{array}$ & 2.1923 & 0.97138 \\
\hline & & $\begin{array}{l}\text { Herfindahl index of union } \\
\text { concentration across all } \\
\text { confederations }\end{array}$ & 0.65301 & 0.25794 \\
\hline
\end{tabular}


Table A.2: Im-Pesaran-Shin stationarity test: tb statistic with one lag

\begin{tabular}{|c|c|c|c|}
\hline Statistic t-bar & Variables in level & $\begin{array}{l}\text { Variables in first } \\
\text { difference }\end{array}$ & Result \\
\hline D9/D1 & -2.145 & $-3.501 * * *$ & $\mathrm{I}(1)$ \\
\hline D9/D5 & -2.384 & $-3.823 * * *$ & $\mathrm{I}(1)$ \\
\hline D5/D1 & -1.695 & $-3.413 * * *$ & $\mathrm{I}(1)$ \\
\hline Total trade openness & -2.121 & $-3.810 * * *$ & $\mathrm{I}(1)$ \\
\hline Total openness in goods & -2.257 & $-3.856^{* * *}$ & $\mathrm{I}(1)$ \\
\hline Total openness in services & -1.492 & $-3.673 * * *$ & $\mathrm{I}(1)$ \\
\hline Education level & $-3.839 * * *$ & $-3.232 * * *$ & $\mathrm{I}(0)$ \\
\hline Foreign Direct Investment & -1.832 & $-2.715 * *$ & $\mathrm{I}(1)$ \\
\hline $\begin{array}{l}\text { Gross Domestic Product Per } \\
\text { Capita }\end{array}$ & -2.273 & $-3.755 * * *$ & $\mathrm{I}(1)$ \\
\hline Inflation rate & $-3.437 * * *$ & $-3.673 * * *$ & $\mathrm{I}(0)$ \\
\hline Confederal Involvement & $-2.678 * * *$ & $-5.259 * * *$ & $\mathrm{I}(0)$ \\
\hline Government Involvement & $-3.792 * * *$ & $-4.854 * * *$ & $\mathrm{I}(0)$ \\
\hline Bargaining Level & $-2.592 * * *$ & $-4.582 * * *$ & $\mathrm{I}(0)$ \\
\hline Herfindal Index & $-2.516^{* * * *}$ & $-4.124 * * *$ & $\mathrm{I}(0)$ \\
\hline Trade Union Density & $-2.468 * * *$ & $-2.998 * * *$ & $\mathrm{I}(0)$ \\
\hline Technological progress & $-2.576 * * *$ & $-3.747 * * *$ & $\mathrm{I}(0)$ \\
\hline
\end{tabular}


Table A.3: Cointegration tests

\begin{tabular}{|c|c|c|c|c|c|c|c|c|c|c|c|c|c|c|c|c|c|c|}
\hline \multirow{2}{*}{$\begin{array}{l}\text { Dependent Variable } \\
\text { Independent variables }\end{array}$} & \multicolumn{5}{|c|}{ D9/D1 } & \multicolumn{5}{|l|}{ D9/D5 } & \multicolumn{5}{|l|}{$D 5 / D 1$} & \multicolumn{3}{|l|}{ FDI } \\
\hline & ڤั & 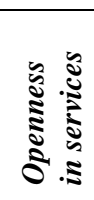 & $\begin{array}{cc}\tilde{y} \\
\vdots \\
\vdots \\
\vdots \\
\vdots \\
\vdots \\
\vdots \\
\vdots \\
\vdots \\
\vdots\end{array}$ & $\widehat{\Omega}$ & ปิ & 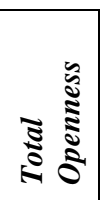 & 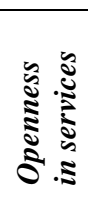 & 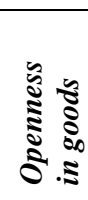 & $\widehat{\widehat{a}}$ & ڤิ & 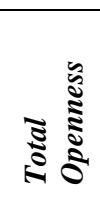 & 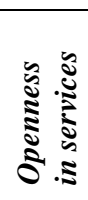 & 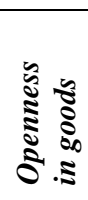 & $\widehat{\mathbf{s}}$ & ปิ & 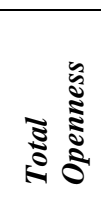 & 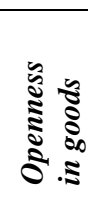 & 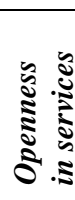 \\
\hline Panel v stat & 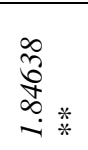 & 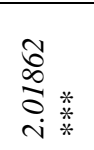 & $\begin{array}{l}\stackrel{N}{\infty} \\
\stackrel{\infty}{\infty} \\
\stackrel{-}{*} *\end{array}$ & $\underset{\substack{n \\
i n}}{i n}$ & 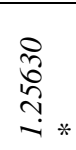 & $\begin{array}{l}\bar{\delta} \\
\stackrel{2}{*} * \\
\grave{2} *\end{array}$ & 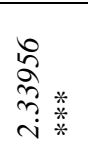 & 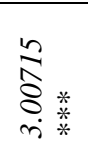 & 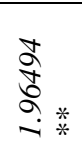 & 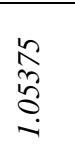 & $\begin{array}{l}\widehat{N} \\
\hat{n} \\
\tilde{0} \\
0\end{array}$ & $\begin{array}{l}\bar{N} \\
\text { D } \\
\stackrel{+}{4} *\end{array}$ & $\begin{array}{l}\hat{\infty} \\
\stackrel{N}{f} \\
\stackrel{0}{0}\end{array}$ & $\begin{array}{l}\mathfrak{a} \\
\stackrel{a}{a} \\
-i\end{array}$ & 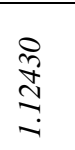 & $\begin{array}{l}8 \\
8 \\
? \\
?\end{array}$ & के & $\begin{array}{l}\overline{6} \\
\overleftarrow{6} \\
\infty \\
i \\
i\end{array}$ \\
\hline Panel rho stat & $\begin{array}{l}\infty \\
\grave{2} \\
\vdots \\
\vdots \\
1\end{array}$ & $\begin{array}{l}\stackrel{8}{\circ} \\
\stackrel{+}{+} \\
\stackrel{+}{1} *\end{array}$ & 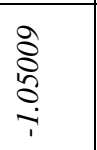 & 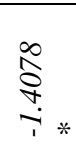 & 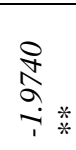 & 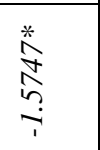 & 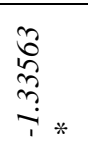 & $\stackrel{\infty}{\stackrel{+}{N}}$ & 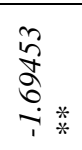 & 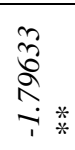 & 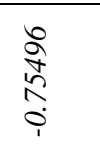 & 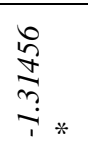 & \begin{tabular}{l}
$\infty$ \\
\multirow{1}{0}{} \\
0 \\
0 \\
0 \\
0
\end{tabular} & $\begin{array}{l}\stackrel{2}{8} \\
\infty \\
\infty \\
i \\
i \\
i\end{array}$ & $\begin{array}{l}\frac{n}{8} \\
8 \\
+1 \\
i\end{array}$ & $\begin{array}{l}\stackrel{0}{ } \\
\stackrel{2}{\Omega} \\
\stackrel{R}{0} \\
i\end{array}$ & 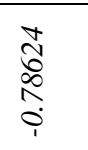 & $\begin{array}{l}n \\
2 \\
\infty \\
\infty \\
\vdots \\
0\end{array}$ \\
\hline Panel pp stat & 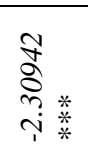 & $\begin{array}{l}\hat{d} \\
\stackrel{\infty}{*} * \\
\dot{*} *\end{array}$ & $\begin{array}{l}\substack{+d \\
2} \\
i \\
i\end{array}$ & $\begin{array}{l}\stackrel{t}{2} \\
\infty \\
\stackrel{\overbrace{}}{*} * \\
i\end{array}$ & $\begin{array}{l}\frac{n}{2} \\
\frac{6}{6} * \\
\dot{1} *\end{array}$ & 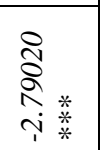 & $\begin{array}{l}\underset{7}{\mathbb{J}} \\
\stackrel{\sim}{*} * \\
i\end{array}$ & 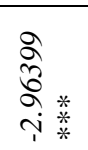 & 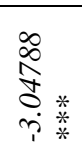 & $\begin{array}{l}8 \\
\stackrel{8}{2} \\
\stackrel{*}{7} * \\
\dot{1} *\end{array}$ & $\begin{array}{l}\stackrel{+}{N} \\
\stackrel{+}{T} *\end{array}$ & 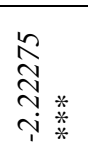 & $\begin{array}{l}\infty \\
\stackrel{\infty}{\alpha} \\
\stackrel{0}{0} \\
i \\
i\end{array}$ & $\begin{array}{l}\mathbb{N} \\
\hat{2} \\
\infty \\
i \\
i \\
i\end{array}$ & $\begin{array}{l}\stackrel{\wp}{\hat{N}} \\
\widehat{\sigma} * * \\
i * *\end{array}$ & $\begin{array}{l}8 \\
8 \\
8 \\
\stackrel{*}{*}\end{array}$ & $\begin{array}{l}\hat{\infty} \\
\infty \\
\infty \\
0 \\
i \\
i\end{array}$ & 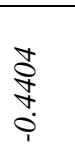 \\
\hline Panel adf stat & 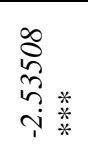 & 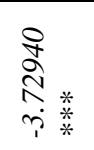 & \begin{tabular}{l}
$\infty$ \\
$\hat{2}$ \\
$\infty$ \\
\multirow{i}{1}{$*$}
\end{tabular} & $\begin{array}{l}\infty \\
\infty \\
\infty \\
0 \\
0 \\
\dot{1} \\
i\end{array}$ & $\begin{array}{l}\frac{n}{\infty} \\
\underset{y}{*} *\end{array}$ & 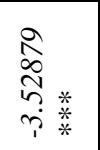 & $\begin{array}{l}\stackrel{N}{\widehat{N}} \\
\hat{\widehat{N}} \\
i\end{array}$ & $\begin{array}{l}\bar{\gamma} \\
\hat{\sigma} \\
\dot{+}\end{array}$ & $\begin{array}{l}\stackrel{?}{\sqrt[6]{6}} \\
\frac{\dot{\pi}}{i} *\end{array}$ & $\begin{array}{l}\frac{\infty}{\sqrt{2}} \\
\stackrel{*}{*} * \\
\ddot{1} * *\end{array}$ & $\begin{array}{l}\hat{\kappa} \\
\stackrel{2}{\infty} \\
\stackrel{*}{*} *\end{array}$ & $\begin{array}{l}\stackrel{\curvearrowright}{\precsim} \\
\stackrel{\nabla}{*} * \\
i \\
i\end{array}$ & $\begin{array}{l}\stackrel{d}{d} \\
\stackrel{T}{T} \\
\stackrel{*}{*} \\
i\end{array}$ & $\begin{array}{l}\infty \\
\sigma \\
\infty \\
\infty \\
\dot{1} *\end{array}$ & \begin{tabular}{l}
7 \\
\multirow{2}{*}{} \\
$\infty$ \\
$\infty$ \\
$i$ \\
$i$ \\
$i$
\end{tabular} & 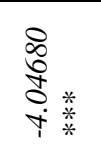 & $\frac{3}{3} \frac{3}{7} *$ & 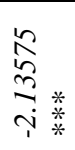 \\
\hline Group rho stat & 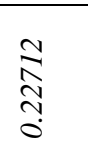 & 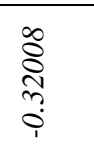 & $\frac{\infty}{\infty}$ & $\frac{\frac{\infty}{8}}{\frac{8}{1}}$ & 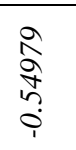 & $\begin{array}{l}0 \\
2 \\
8 \\
? \\
? \\
1\end{array}$ & $\begin{array}{l}n \\
\hat{2} \\
\vdots \\
\vdots \\
i\end{array}$ & $\begin{array}{l}0 \\
\infty \\
0 \\
0 \\
0 \\
i\end{array}$ & $\begin{array}{l}\tilde{2} \\
\hat{\alpha} \\
\dot{0} \\
i\end{array}$ & $\begin{array}{l}\overline{6} \\
\mathbb{N} \\
0 \\
0 \\
i\end{array}$ & 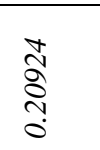 & $\begin{array}{l}0 \\
6 \\
0 \\
0 \\
0\end{array}$ & $\begin{array}{l}8 \\
\vdots \\
n \\
0\end{array}$ & 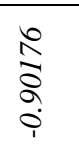 & 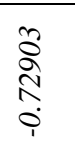 & 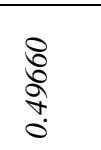 & $\begin{array}{l}\frac{9}{7} \\
\frac{1}{0} \\
0 \\
0\end{array}$ & $\frac{i}{\sqrt{n}}$ \\
\hline Group pp stat & 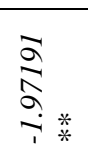 & 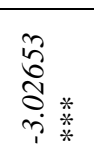 & 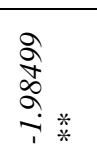 & 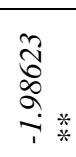 & $\begin{array}{l}\stackrel{̃}{\mathbb{N}} \\
\hat{\widehat{N}} \\
\stackrel{*}{*} *\end{array}$ & 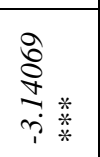 & $\begin{array}{l}\vec{N} \\
\stackrel{N}{*} * \\
i \\
i\end{array}$ & $\begin{array}{l}\stackrel{2}{n} \\
\stackrel{n}{n} * \\
i *\end{array}$ & 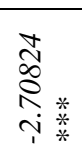 & 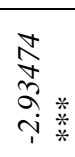 & 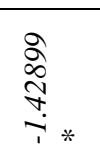 & \begin{tabular}{l}
8 \\
8 \\
+7 \\
\hdashline \\
7
\end{tabular} & 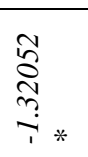 & $\begin{array}{l}\widetilde{\mho} \\
\stackrel{\overbrace{}}{2} \\
\stackrel{*}{*} *\end{array}$ & $\begin{array}{l}2 \\
\infty \\
0 \\
0 \\
\vdots \\
i \\
i\end{array}$ & 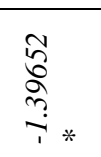 & $\begin{array}{l}\overline{8} \\
\infty \\
\stackrel{5}{1} \\
i\end{array}$ & $\frac{\stackrel{d}{\sigma}}{\stackrel{\vdots}{0}}$ \\
\hline Group adf stat & $\begin{array}{l}\stackrel{2}{2} \\
\grave{\lambda} \\
\stackrel{*}{*} * \\
i\end{array}$ & 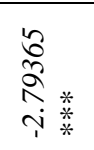 & $\begin{array}{l}\text { J } \\
\text { ठे * } \\
i \text { * }\end{array}$ & $\begin{array}{l}\infty \\
\infty \\
\infty \\
\infty \\
i \\
i\end{array}$ & $\begin{array}{l}\stackrel{R}{\hat{n}} \\
\text { है } \\
\dot{i} * *\end{array}$ & $\begin{array}{l}\infty \\
\infty \\
\infty \\
\infty \\
+ \\
+\end{array}$ & 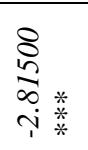 & 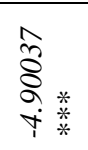 & $\begin{array}{l}\bar{\pi} \\
\infty \\
\infty \\
i \\
i\end{array}$ & $\begin{array}{l}\infty \\
\infty \\
0 \\
0 \\
\dot{t} \\
\dot{1}\end{array}$ & $\begin{array}{l}\infty \\
\infty \\
\infty \\
\infty \\
+* \\
+*\end{array}$ & $\begin{array}{l}m \\
\hat{N} \\
\stackrel{\infty}{-} *\end{array}$ & 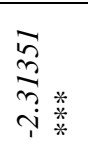 & $\stackrel{\hat{\infty}}{\underset{\lambda}{*} *}$ & 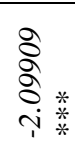 & $\begin{array}{l}\hat{\sigma} \\
\stackrel{\sigma}{0} * \\
\dot{r} *\end{array}$ & $\begin{array}{l}\text { बे } \\
\hat{\alpha} \\
\infty \\
\dot{1}\end{array}$ & $\begin{array}{l}\stackrel{2}{\approx} \\
\stackrel{2}{\infty} \\
\stackrel{+}{i} *\end{array}$ \\
\hline
\end{tabular}


Table A.4. ECM results using LSDVC estimator (openness variables)

\begin{tabular}{|c|c|c|c|c|c|c|c|c|c|}
\hline$\Delta$ INEQ & D9/D1 & D9/D5 & D5/D1 & D9/D1 & D9/D5 & D5/D1 & D9/D1 & D9/D5 & D5/D1 \\
\hline Method & LSDVC & LSDVC & LSDVC & LSDVC & LSDVC & LSDVC & LSDVC & LSDVC & LSDVC \\
\hline \multirow[t]{2}{*}{$\Delta \operatorname{INEQ}(\mathrm{t}-1)$} & $-0.1991 * *$ & $-0.2100 * *$ & $-0.1924 * *$ & $-0.2051 * *$ & $-0.2074 * *$ & $-0.2030 * *$ & $-0.1966^{* * *}$ & $-0.2017 * *$ & $-0.1996^{* * * *}$ \\
\hline & $(0.0817)$ & $(0.0838)$ & $(0.0850)$ & $(0.0828)$ & $(0.0844)$ & $(0.0865)$ & $(0.0752)$ & $(0.0818)$ & $(0.0772)$ \\
\hline Error Correction & $-0.1339 * * *$ & $-0.1553 * * *$ & $-0.1438 * * *$ & $-0.1280 * * *$ & $-0.1594 * * *$ & $-0.1248 * * *$ & $-0.1459 * * *$ & $-0.1670 * * *$ & $-0.1258 * * *$ \\
\hline Term & $(0.0416)$ & $(0.0572)$ & $(0.0487)$ & $(0.0407)$ & $(0.0566)$ & $(0.0482)$ & $(0.0445)$ & $(0.0616)$ & $(0.0484)$ \\
\hline$\Delta$ Total trade & 0.0008 & -0.0002 & 0.0015 & & & & & & \\
\hline openness & $(0.0024)$ & $(0.0009)$ & $(0.0010)$ & & & & & & \\
\hline$\Delta$ Total trade & $0.0047 * * *$ & -0.0001 & $0.0024 * * *$ & & & & & & \\
\hline Openness (t-1) & $(0.0015)$ & $(0.0007)$ & $(0.0007)$ & & & & & & \\
\hline$\Delta$ Trade openness & & & & 0.0010 & -0.0001 & 0.0014 & & & \\
\hline in goods & & & & $(0.0032)$ & $(0.0013)$ & $(0.0014)$ & & & \\
\hline$\Delta$ Trade openness & & & & $0.0065 * * *$ & 0.0004 & $0.0032 * * *$ & & & \\
\hline in goods (t-1) & & & & $(0.0023)$ & $(0.0010)$ & $(0.0010)$ & & & \\
\hline$\Delta$ Trade openness & & & & & & & -0.0038 & 0.0000 & -0.0018 \\
\hline in services & & & & & & & $(0.0049)$ & $(0.0022)$ & $(0.0021)$ \\
\hline$\Delta$ Trade openness & & & & & & & 0.0051 & 0.0006 & 0.0003 \\
\hline in services (t-1) & & & & & & & $(0.0166)$ & $(0.0071)$ & $(0.0074)$ \\
\hline \multirow[t]{2}{*}{ Education } & -0.0103 & -0.0047 & -0.0032 & -0.0097 & -0.0047 & -0.0025 & -0.0122 & -0.0055 & -0.0012 \\
\hline & $(0.0120)$ & $(0.0051)$ & $(0.0057)$ & $(0.0119)$ & $(0.0051)$ & $(0.0056)$ & $(0.0119)$ & $(0.0055)$ & $(0.0058)$ \\
\hline \multirow[t]{2}{*}{ Techn Progress (t-1) } & -0.0577 & $-0.0629 *$ & 0.0103 & -0.0711 & $-0.0617 *$ & 0.0020 & -0.0455 & -0.0596 & 0.0095 \\
\hline & $(0.0820)$ & $(0.0364)$ & $(0.0352)$ & $(0.0819)$ & $(0.0363)$ & $(0.0353)$ & $(0.0835)$ & $(0.0378)$ & $(0.0354)$ \\
\hline \multirow[t]{2}{*}{ Inflation (t-1) } & 0.0043 & 0.0005 & 0.0025 & 0.0042 & 0.0005 & 0.0024 & 0.0030 & 0.0005 & 0.0016 \\
\hline & $(0.0040)$ & $(0.0017)$ & $(0.0017)$ & $(0.0040)$ & $(0.0017)$ & $(0.0017)$ & $(0.0040)$ & $(0.0017)$ & $(0.0017)$ \\
\hline Trade Union & -0.1216 & -0.0194 & -0.0837 & -0.0992 & -0.0184 & -0.0721 & -0.1158 & -0.0282 & -0.0668 \\
\hline density (t-1) & $(0.1592)$ & $(0.0741)$ & $(0.0693)$ & $(0.1587)$ & $(0.0744)$ & $(0.0696)$ & $(0.1692)$ & $(0.0781)$ & $(0.0708)$ \\
\hline Confederal & 0.0023 & -0.0003 & 0.0008 & 0.0021 & -0.0004 & 0.0009 & 0.0022 & -0.0004 & 0.0012 \\
\hline involvement (t-1) & $(0.0026)$ & $(0.0011)$ & $(0.0012)$ & $(0.0026)$ & $(0.0011)$ & $(0.0012)$ & $(0.0026)$ & $(0.0011)$ & $(0.0012)$ \\
\hline Government & -0.0024 & 0.0011 & $-0.0021 * *$ & -0.0026 & 0.0010 & $-0.0021^{* *}$ & -0.0021 & 0.0011 & $-0.0019 *$ \\
\hline invlovement (t-1) & $(0.0021)$ & $(0.0009)$ & $(0.0009)$ & $(0.0021)$ & $(0.0009)$ & $(0.0010)$ & $(0.0022)$ & $(0.0010)$ & $(0.0010)$ \\
\hline Bargaining Level & $-0.0114 *$ & $-0.0086^{* * *}$ & 0.0020 & $-0.0131 * *$ & $-0.0089 * * *$ & 0.0010 & $-0.0111^{*}$ & $-0.0085 * * *$ & 0.0015 \\
\hline$(\mathrm{t}-1)$ & $(0.0064)$ & $(0.0029)$ & $(0.0027)$ & $(0.0063)$ & $(0.0028)$ & $(0.0026)$ & $(0.0060)$ & $(0.0028)$ & $(0.0024)$ \\
\hline Herfindahl index & $-0.2221 * *$ & -0.0633 & -0.0771 & $-0.2354 * *$ & -0.0666 & $-0.0817^{*}$ & $-0.2282 * *$ & -0.0634 & -0.0771 \\
\hline$(\mathrm{t}-1)$ & $(0.1086)$ & $(0.0457)$ & $(0.0474)$ & $(0.1100)$ & $(0.0461)$ & $(0.0479)$ & $(0.1121)$ & $(0.0459)$ & $(0.0499)$ \\
\hline Observations & 240 & 240 & 240 & 240 & 240 & 240 & 240 & 240 & 240 \\
\hline
\end{tabular}

Notes: Robust standard errors in parentheses. * significant at 10\%, ** significant at $5 \%, * * *$ significant at $1 \%$ level. 
Figure A5. Development of the main variables over time

Trends in D9/D1 indicators for the sample countries, 1980-2005

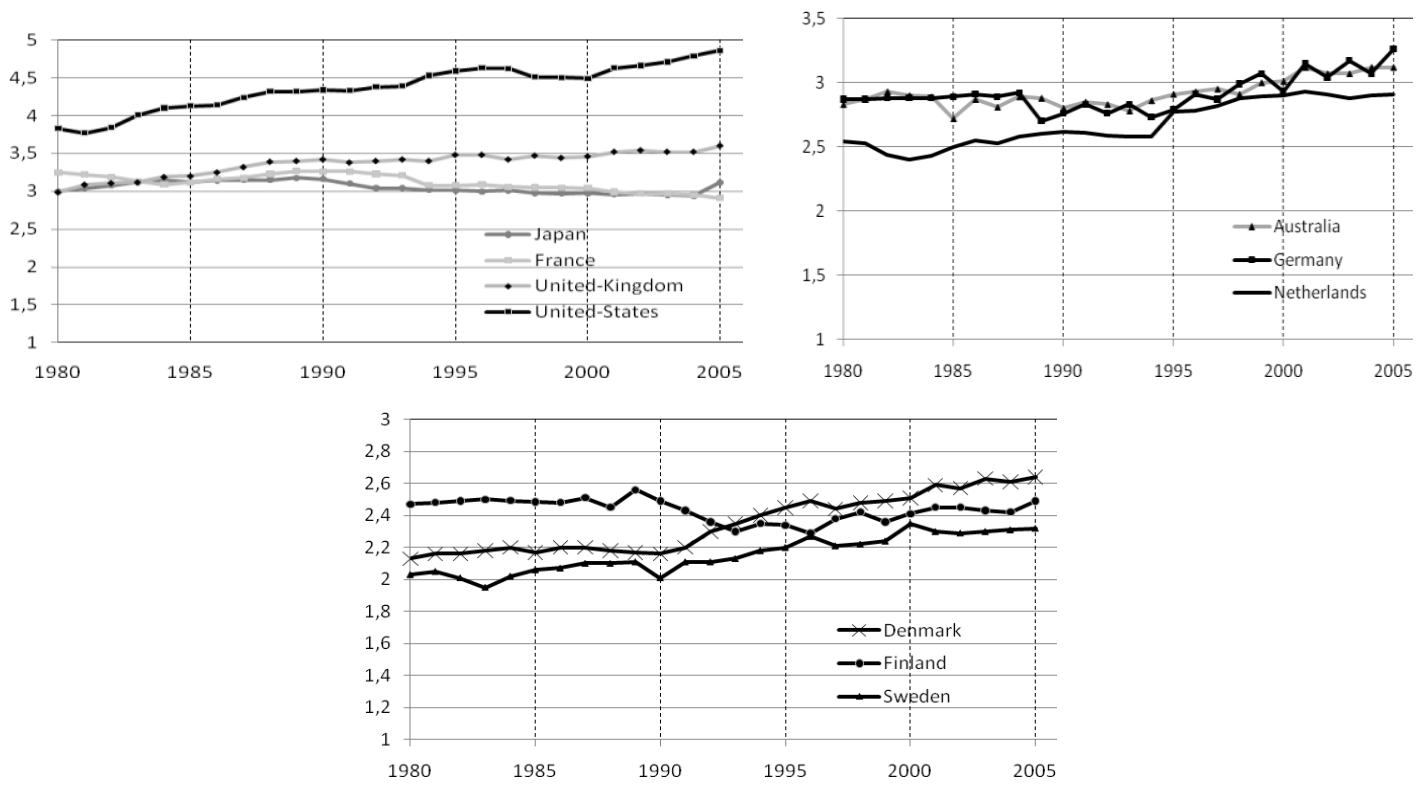

Trends in D5/D1 indicators for the sample countries, 1980-2005

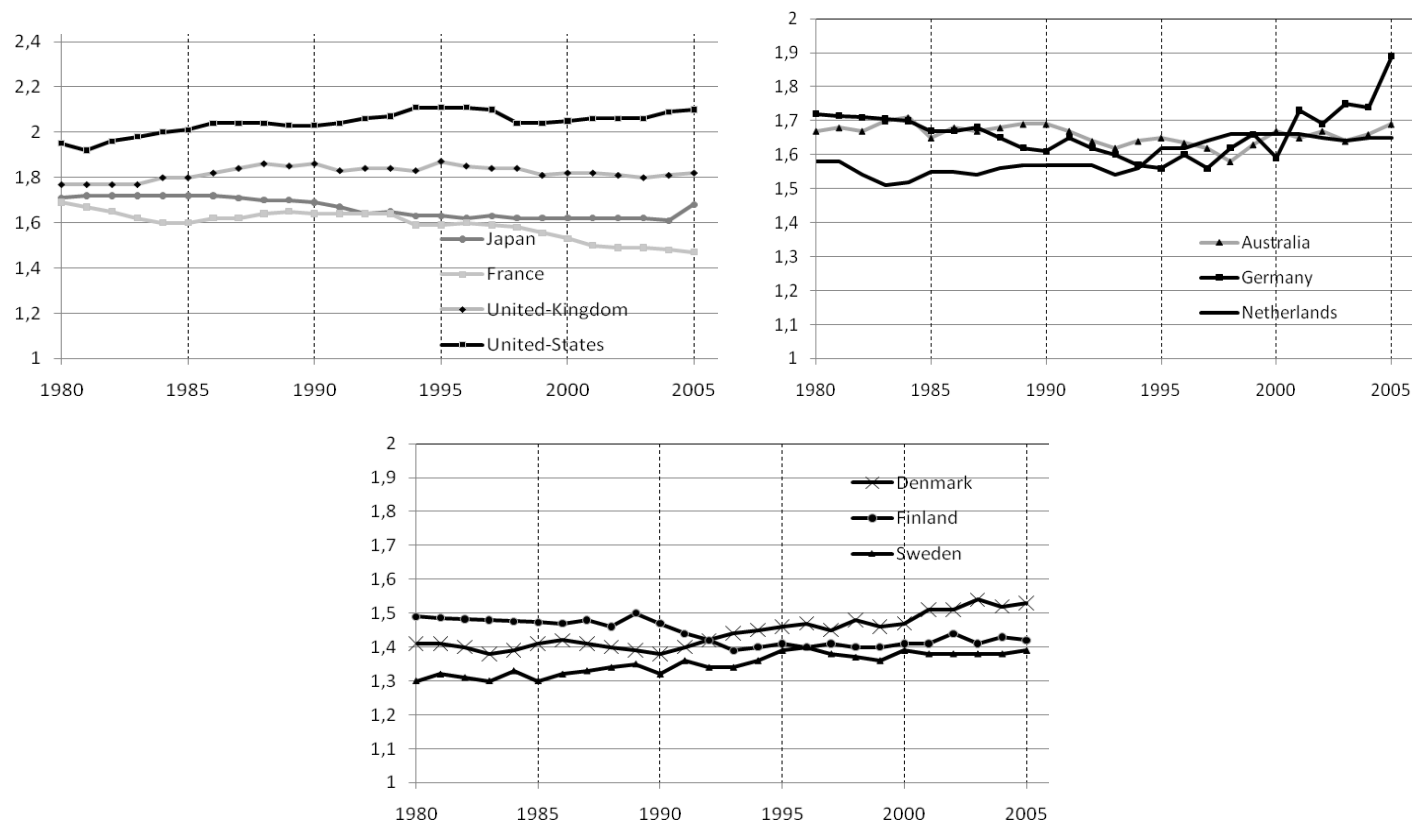


Trends in D9/D5 indicators for the sample countries, 1980-2005
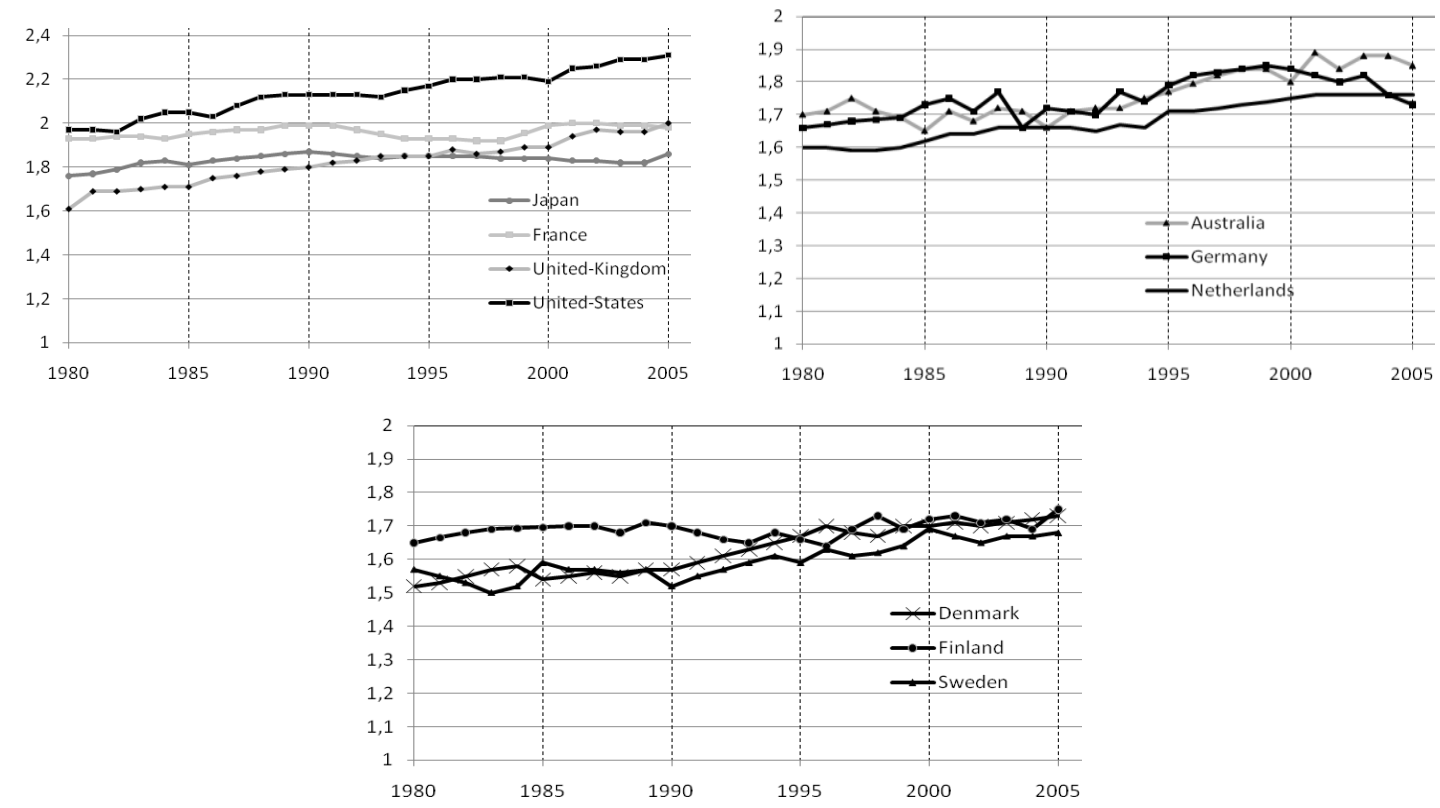

Trends in openness trade of services for the sample countries, 1980-2005

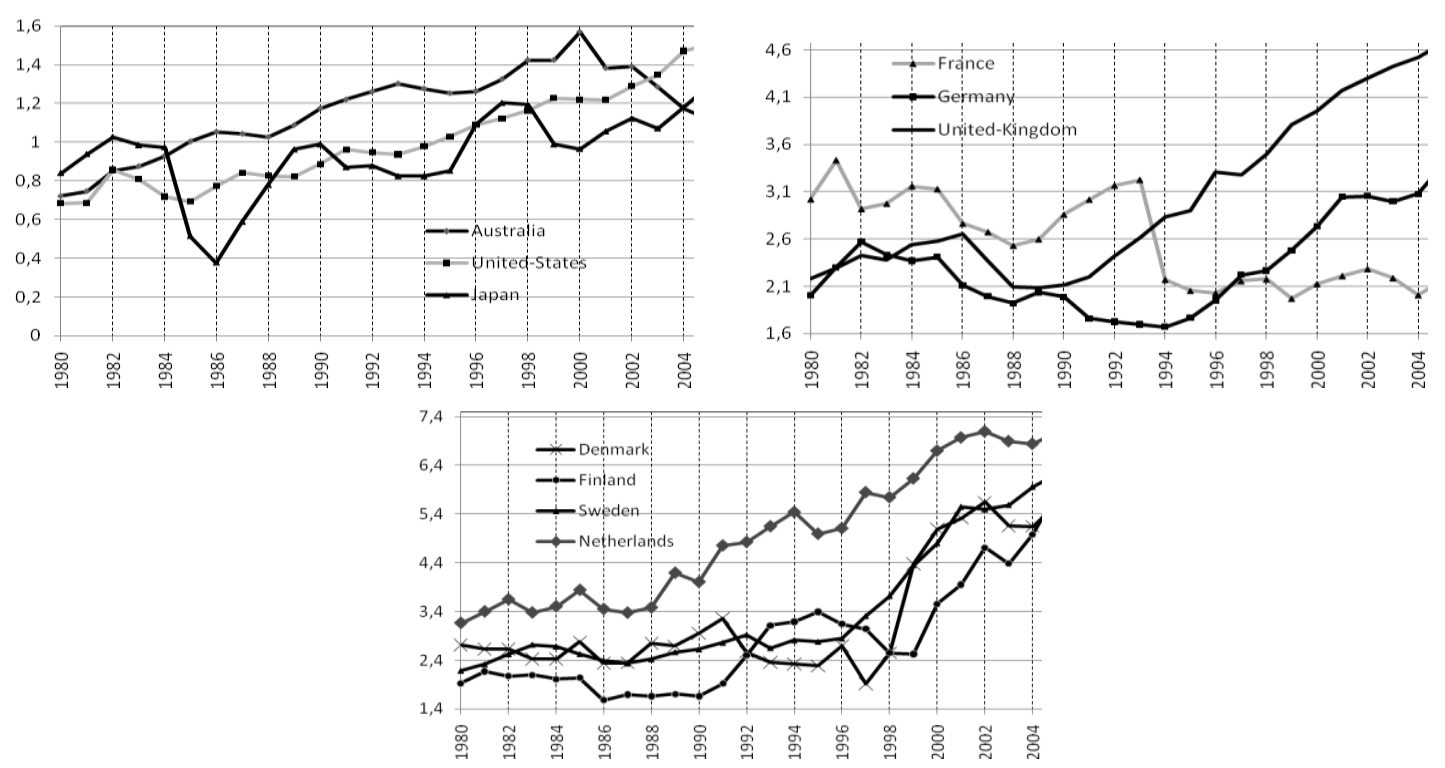


Trends in openness trade of goods for the sample countries, 1980-2005

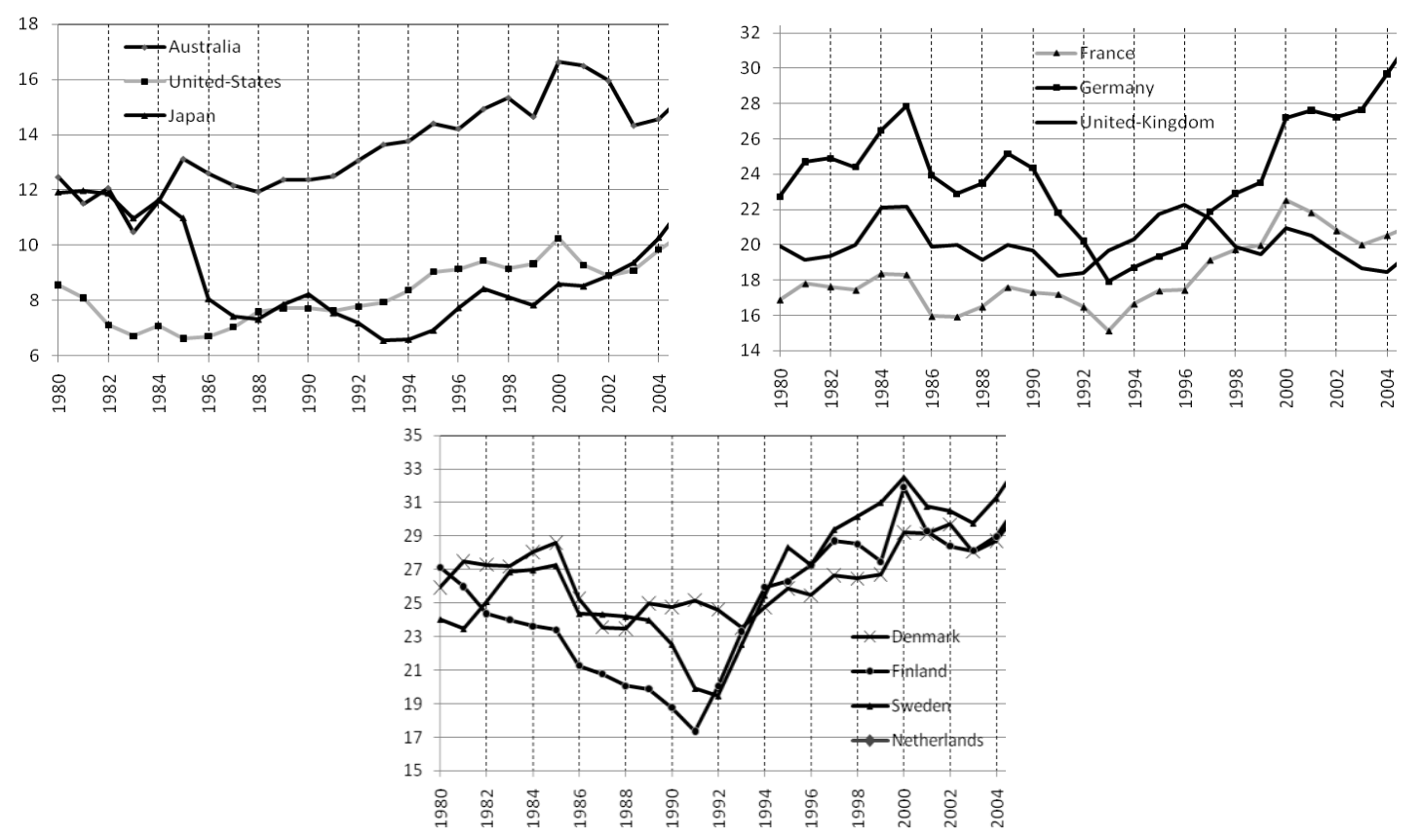

Trends in total openness trade (goods + services) for the sample countries, 1980-2005
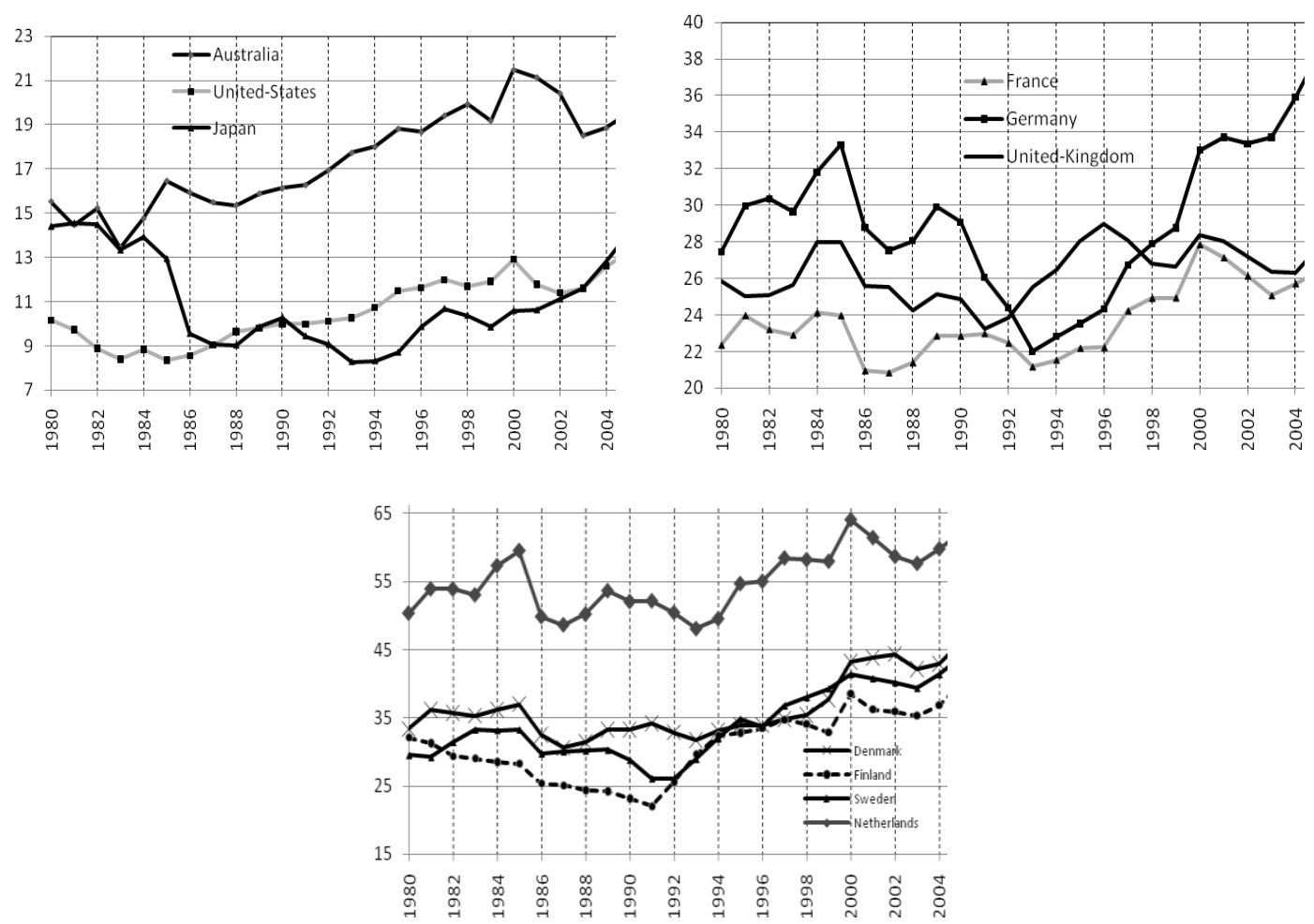
Trends in GDP per capita for the sample countries, 1980-2005
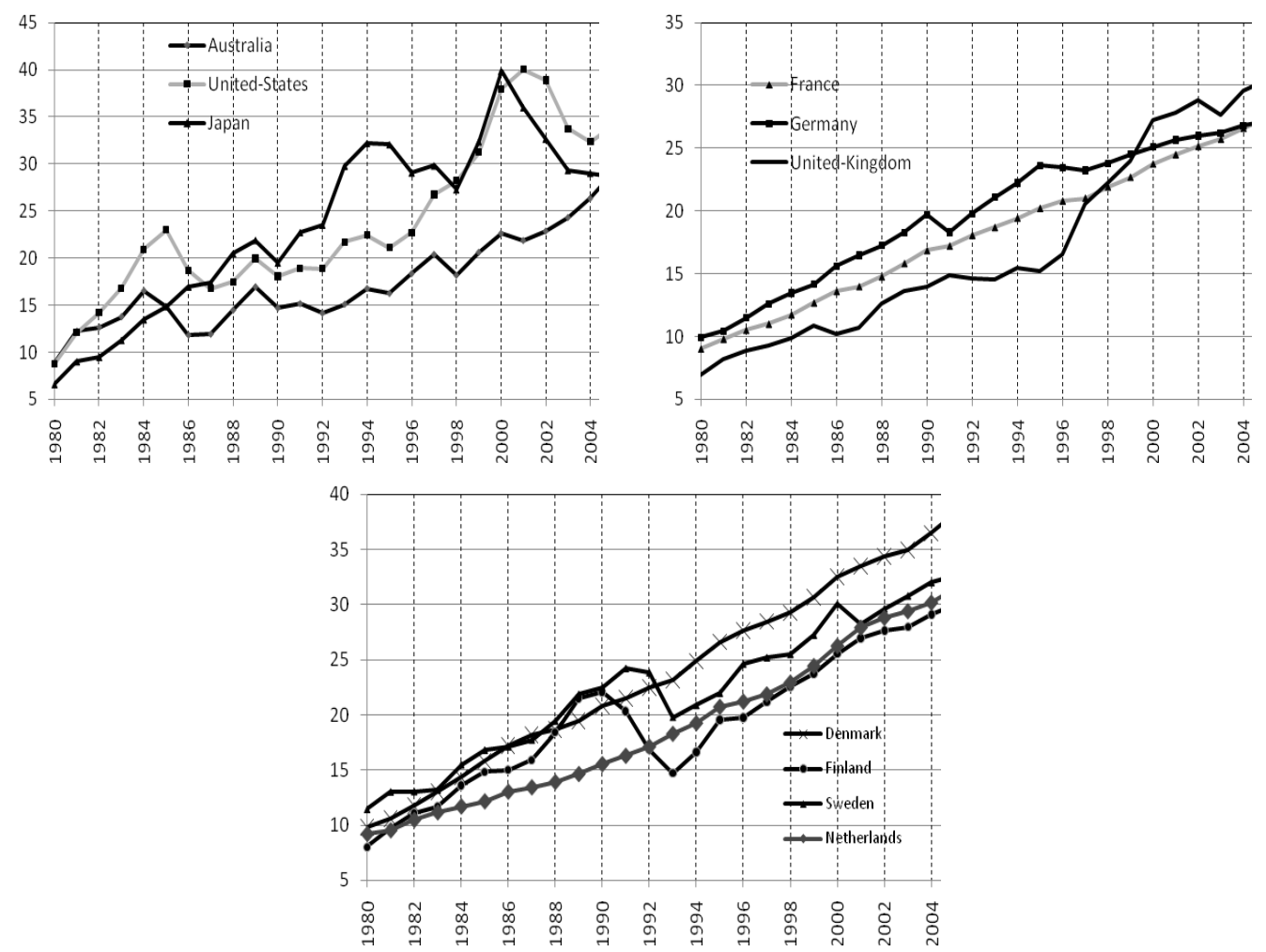

Trends in foreign direct investment stocks (in \% of GDP), for the sample countries, 1980-2005
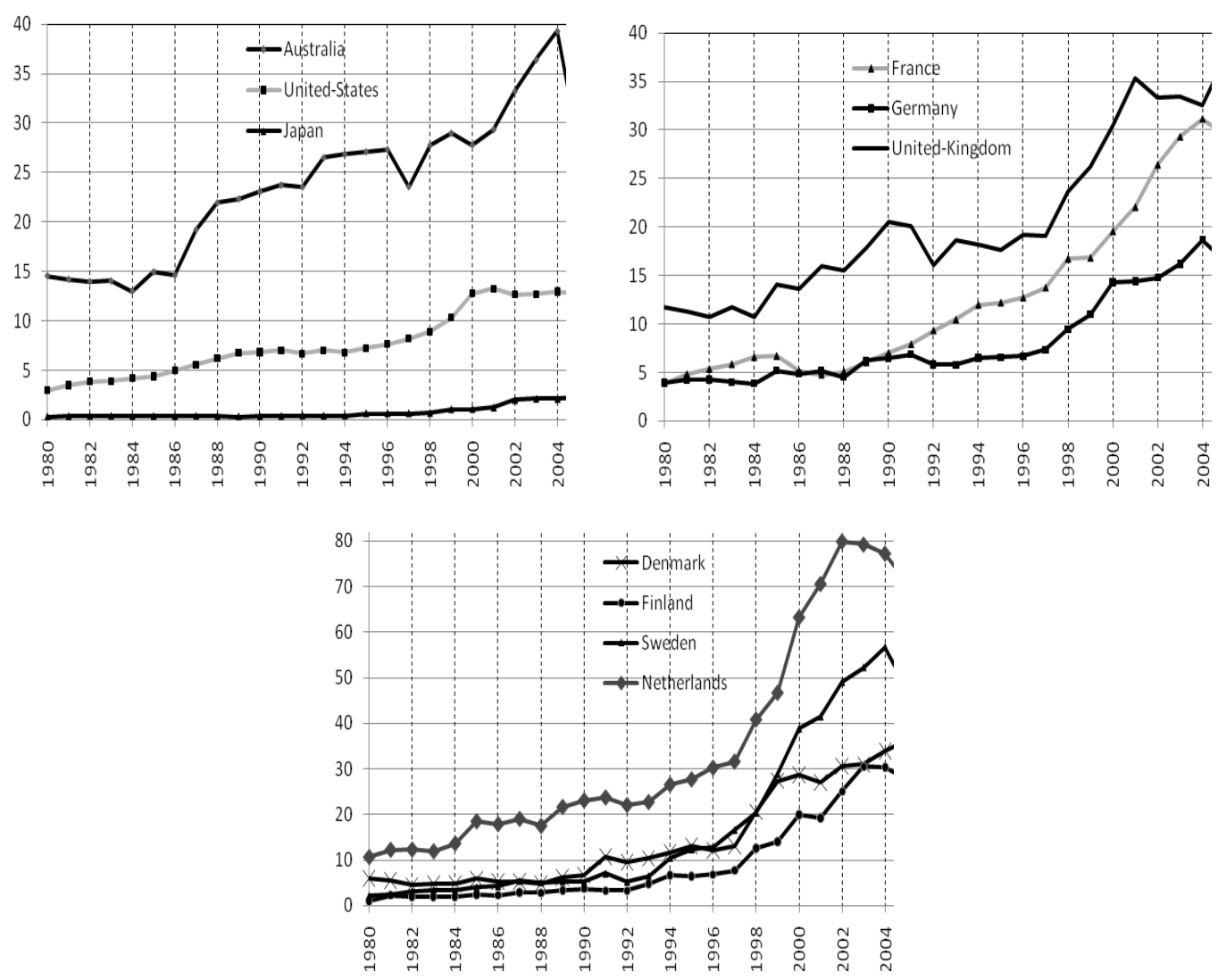
Trends in inflation for the sample countries, $1980-2005$
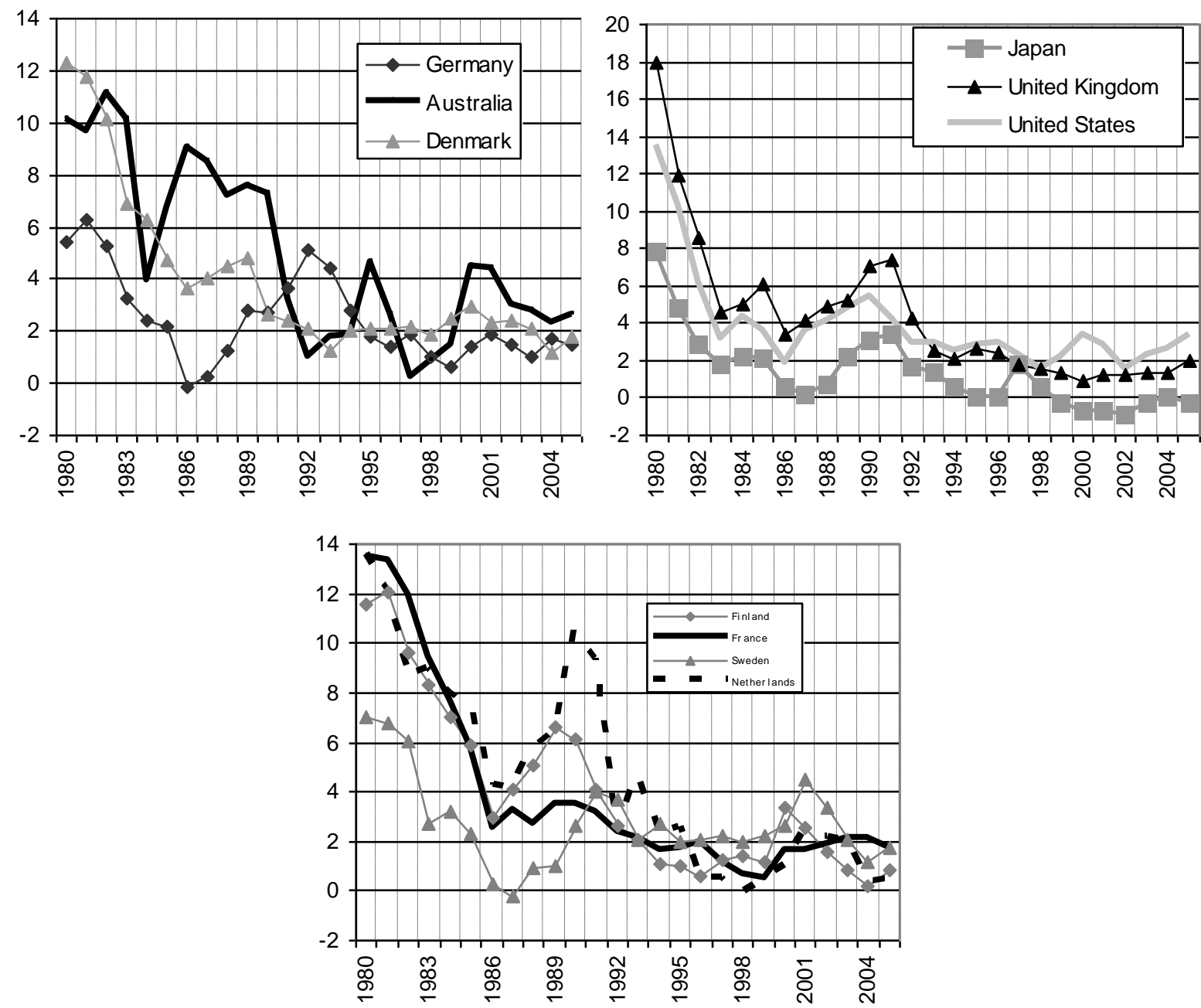
Trends in education (average number of schooling years) for the sample countries, 1980-2005
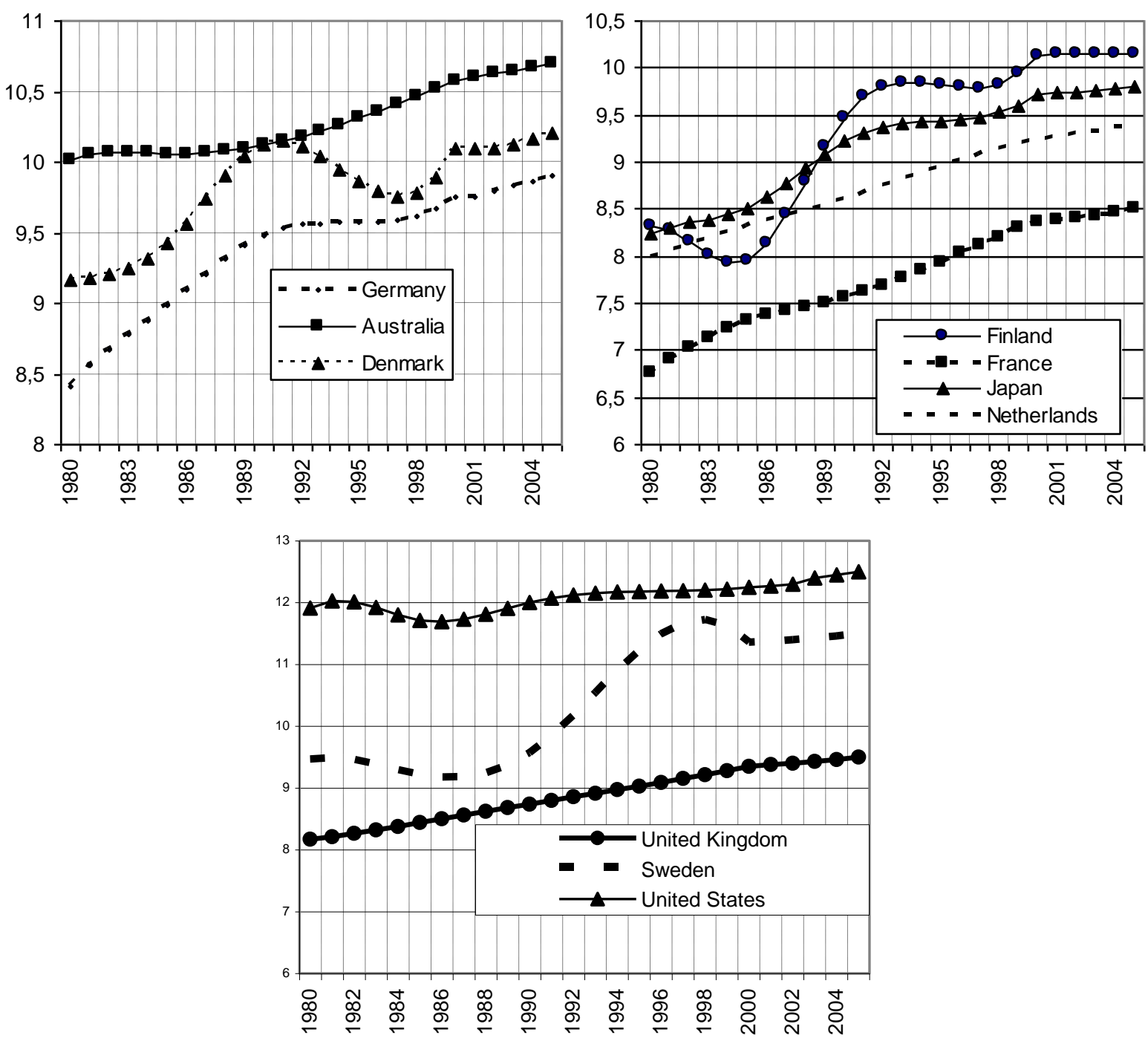
Annual growth of the information and communication stock (\%)

for the sample countries, 1980-2005
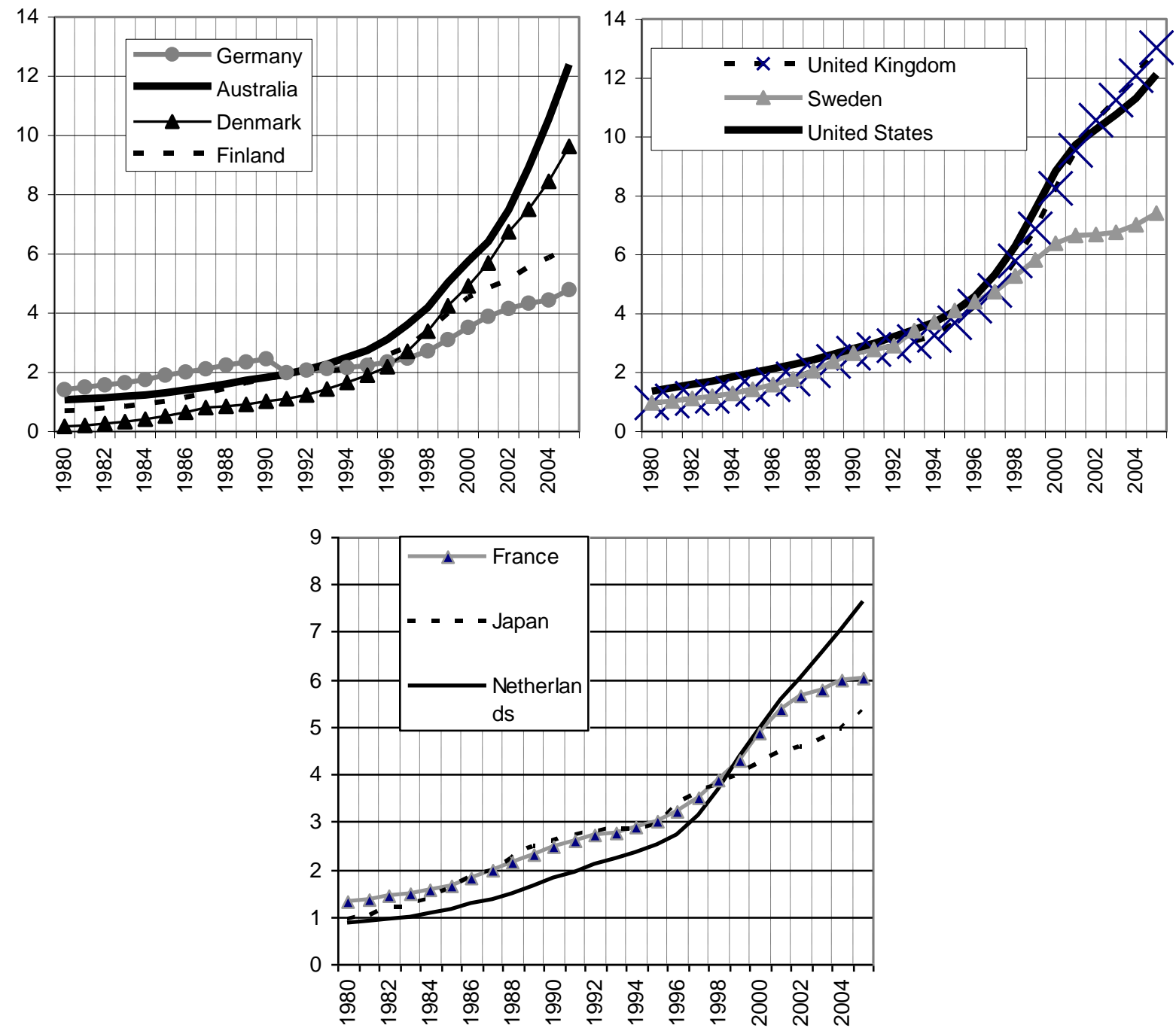
Figure A6. Scatter plots between the main variables

Scatter plots of inequalities indicators and foreign direct investment (stocks, in \% of GDP), 1980-2005
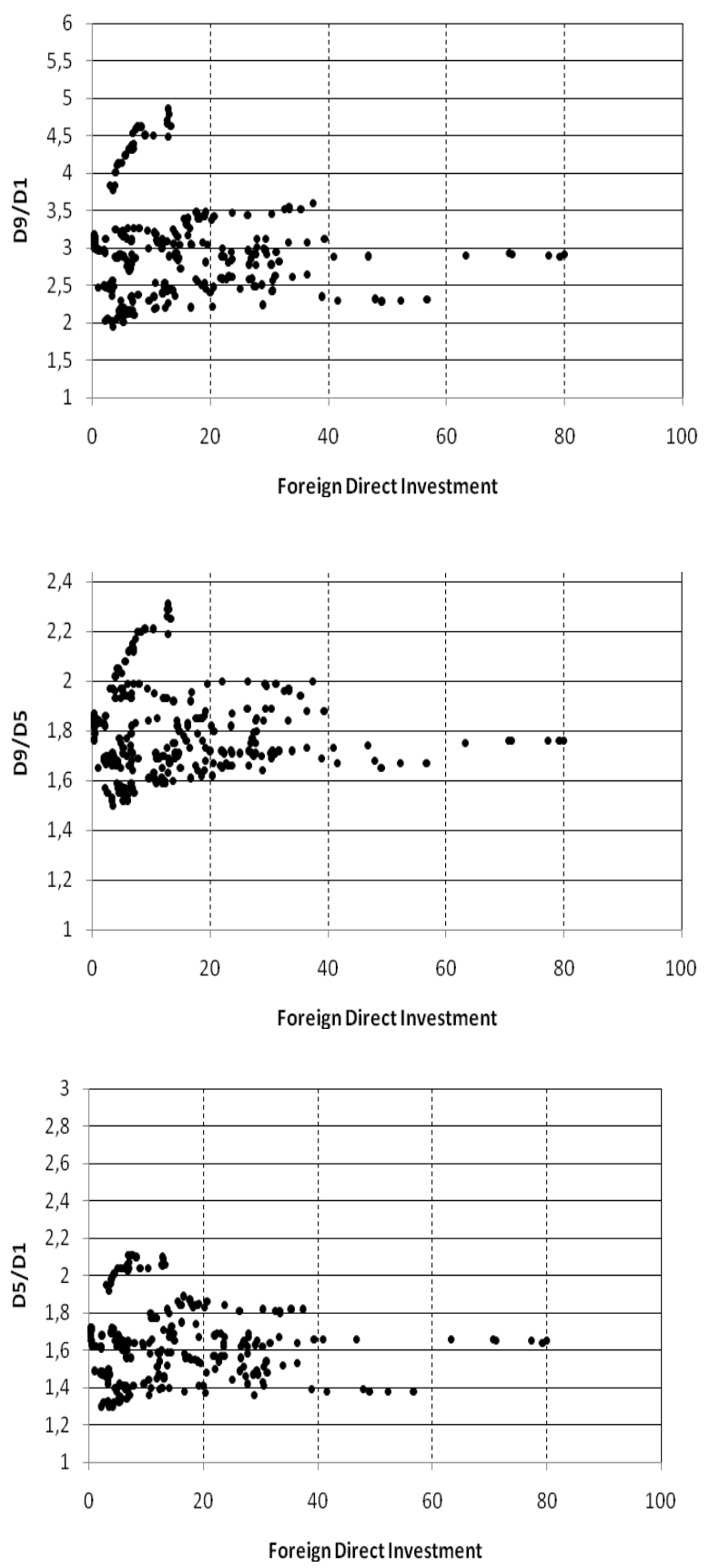
Scatter plots of inequalities indicators and openness trade of services, 1980-2005
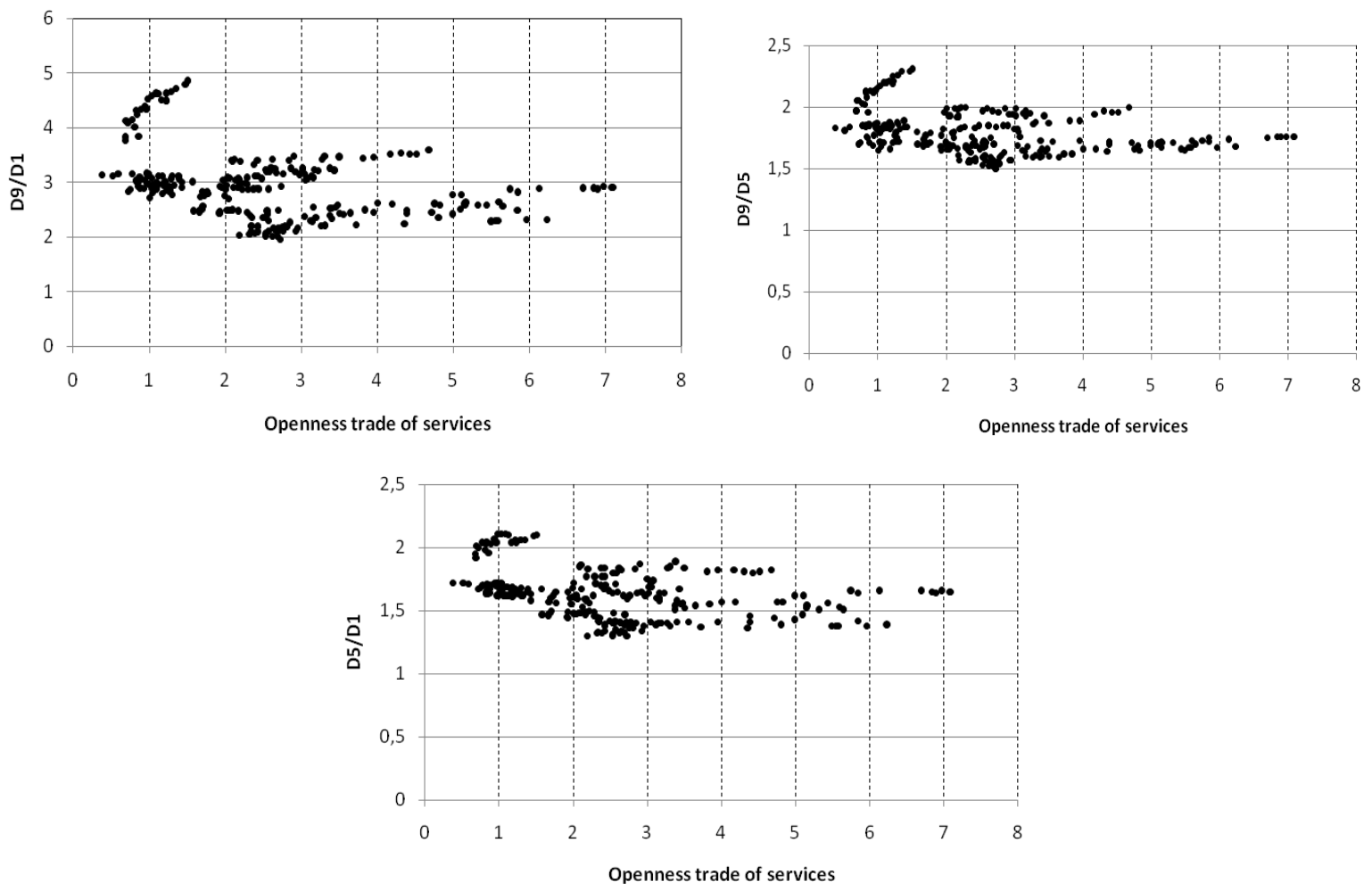

Scatter plots of inequalities indicators and openness trade of goods, 1980-2005
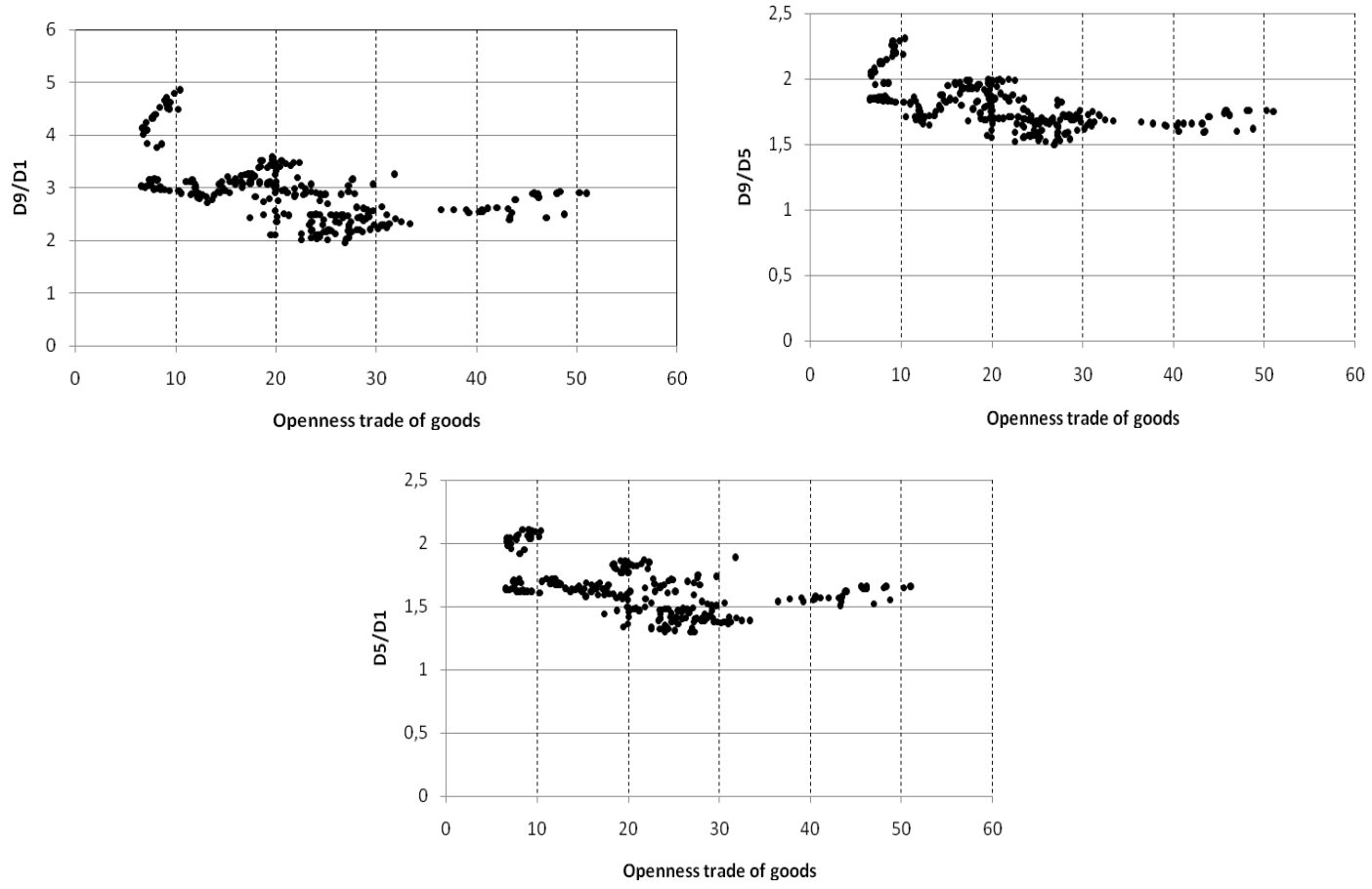
Scatter plots of inequalities indicators and total openness trade (goods + services), 19802005
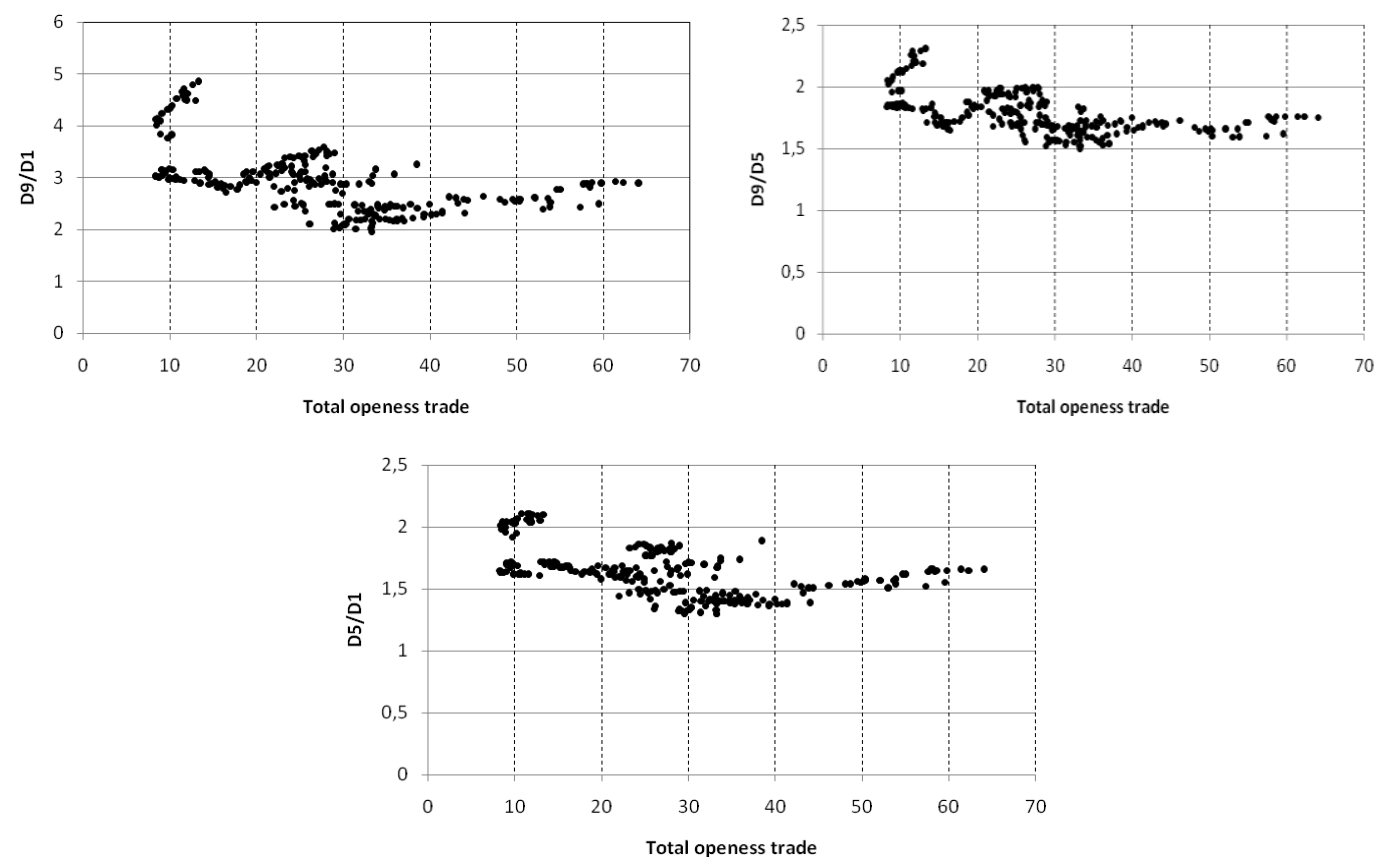

Scatter plots of inequalities indicators and inflation, 1980-2005
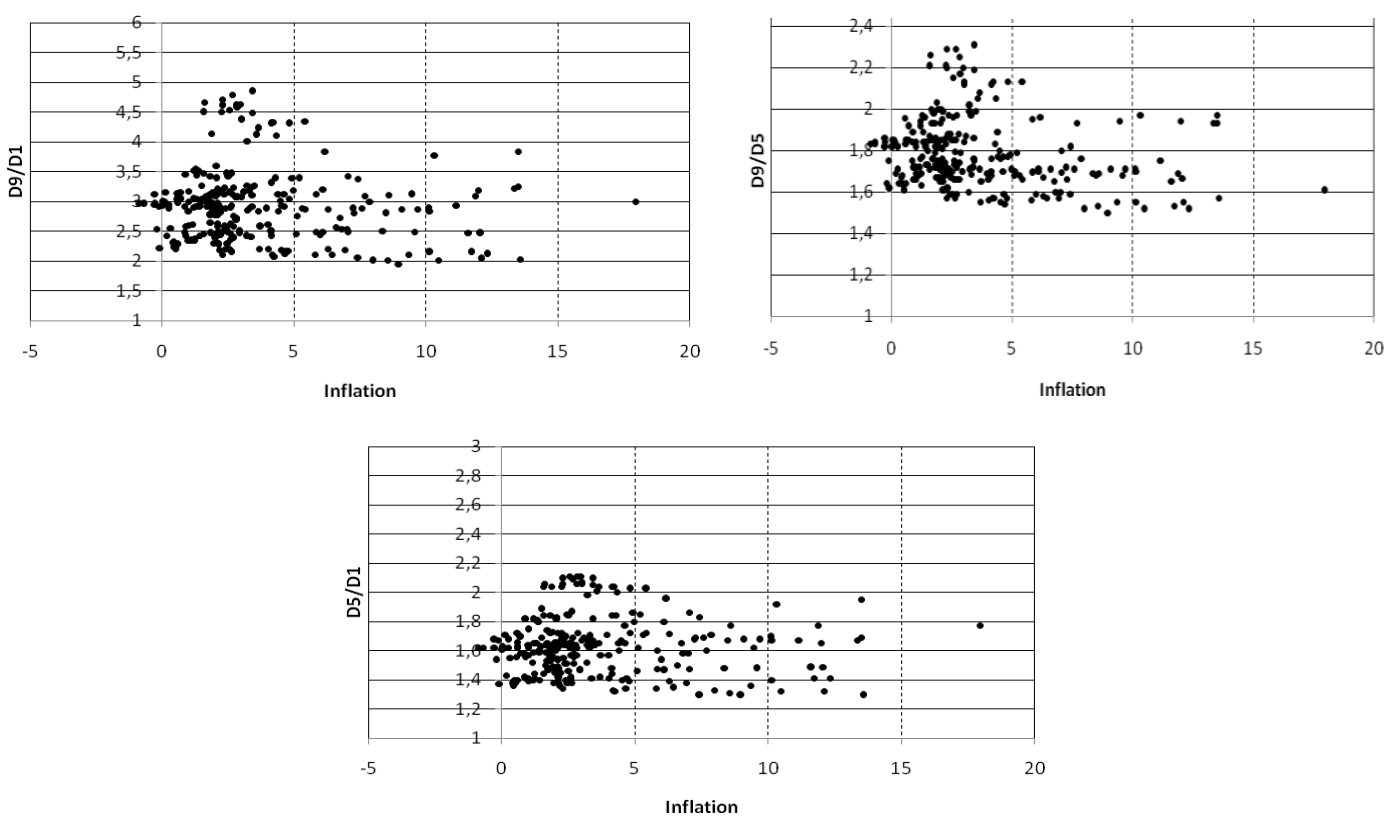
Scatter plots of inequalities indicators and GDP per capita, 1980-2005
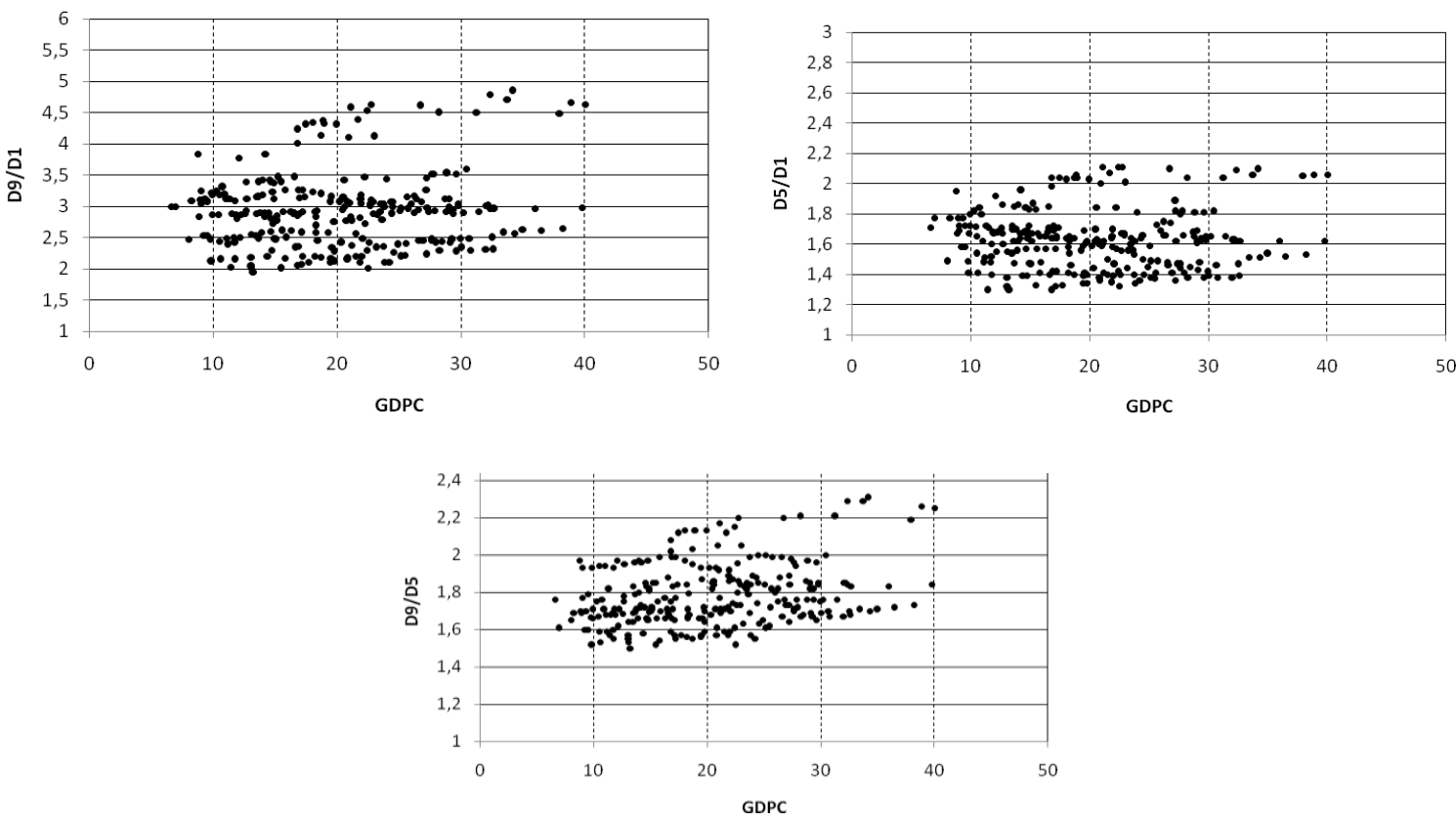

Scatter plots of inequalities indicators and education, 1980-2005
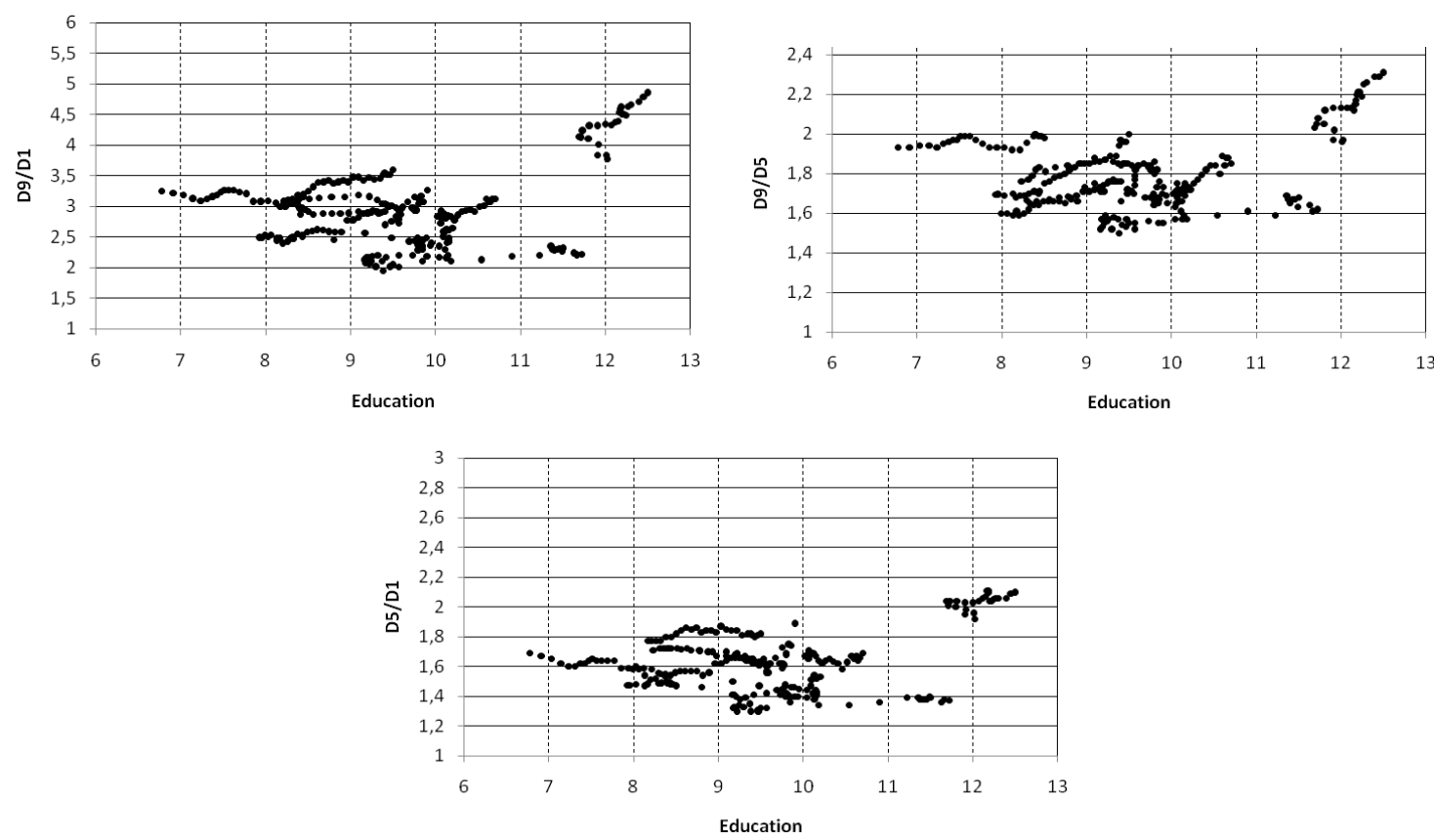
Scatter plots of inequalities indicators and the annual growth of the information and communication stock $(\%), \mathbf{1 9 8 0 - 2 0 0 5}$
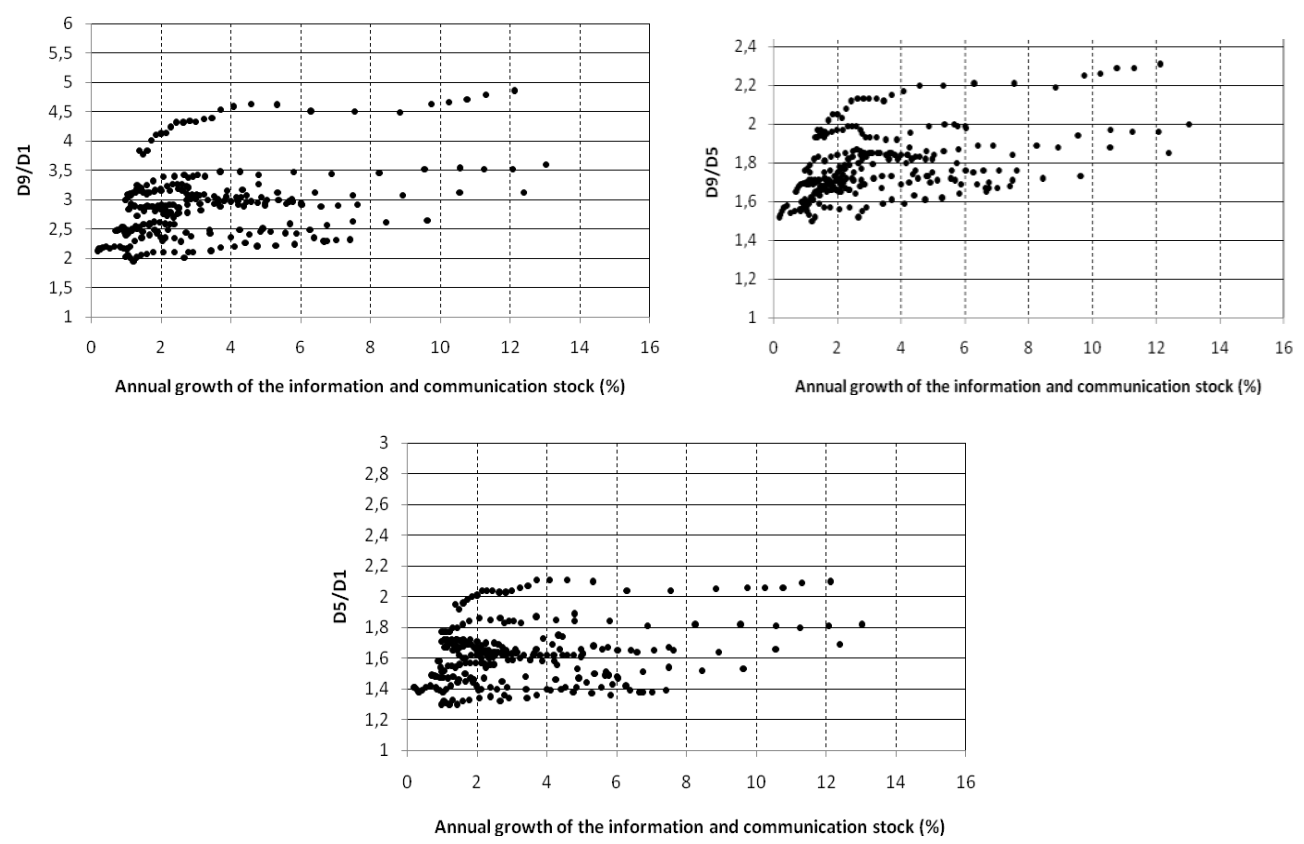